University of Tennessee College of Law

Legal Scholarship Repository: A Service of the Joel A. Katz Law Library

3-2021

\title{
When Hospitals Sue Patients
}

Isaac Buck

Follow this and additional works at: https://ir.law.utk.edu/utklaw_facpubs

Part of the Law Commons

\section{Recommended Citation}

Buck, Isaac, "When Hospitals Sue Patients" (2021). UTK Law Faculty Publications. 37.

https://ir.law.utk.edu/utklaw_facpubs/37

This Article is brought to you for free and open access by the Faculty Work at Legal Scholarship Repository: A Service of the Joel A. Katz Law Library. It has been accepted for inclusion in UTK Law Faculty Publications by an authorized administrator of Legal Scholarship Repository: A Service of the Joel A. Katz Law Library. For more information, please contact eliza.boles@utk.edu. 


\section{TS THE UNVERSITY OF TENNESSEE \\ KNOXVILLE}

COLLEGE OF LAW
Legal Studles

Research Paper Series

Research Paper \#405

April 2021

\title{
When Hospitals Sue Patients
}

\author{
Isaac D. Buck \\ 73 Hastings L.J. \\ (Forthcoming 2021-22) \\ This paper may be downloaded without charge \\ from the Social Science Research Network Electronic library at \\ http://ssrn.com/abstract $=\mathbf{3 8 1 2 3 5 6}$
}

Learn more about the University of Tennessee College of Law: law.utk.edu 
To be published in 73 Hastings L.J. _ (forthcoming 2021-22).

\title{
WHEN HOSPITALS SUE PATIENTS
}

\author{
By Isaac D. Buck
}

Grimly demonstrated by the COVID-19 pandemic, hospitals serve as the central hub of American health care. Increasingly exercising market power, setting clinical standards, and fostering innovation, hospitals' influence over health care delivery and access is unmatched. They are the behemoth in the delivery chain, exerting unrivaled control.

As such, hospitals have naturally become the locus of the worst of the collision between consumerism and universality, between cost and access-a gloomy setting for citizens who simply cannot afford the health care they need to flourish, or to survive. Indeed, the price of American health care-a cost that is increasingly borne by American patientsis unsustainable. Those costs continue to rise thanks to a pernicious mix of increasingly brittle and ineffective insurance plans, a squeeze on public funding, and a lack of price sensitivity among the providers of American health care. Patients are suffering. And hospitals aren't getting paid.

In a predictable but catastrophic turn, hospitals are suing their former patients for unpaid medical bills. Litigation has replaced systematic financing. The operating room has been swapped for the courtroom. And adversarial proceedings now follow the Hippocratic Oath.

Tracking the phenomenon of these lawsuits, this article lays out the harms that result to the American health care system. When hospitals sue patients, they harm public health and destroy patient trust. And they shatter widely-held beliefs, highlighting the inadequacy of policy goals and the inequity of health finance rules.

Further, once and for all, they expose the failure of the consumer-based paradigm of American health care, spotlighting the inapplicability of moral hazard, and demonstrating the means by which individuals with private insurance and high deductibles-a rapidly growing population in the United States-are inadequately protected against the very actors that undertake to protect their health and wellbeing. This article makes the moral, legal, and policybased argument that hospital lawsuits against former patients must be brought to an end. American patients simply cannot afford it. 


\section{TABLE OF CONTENTS}

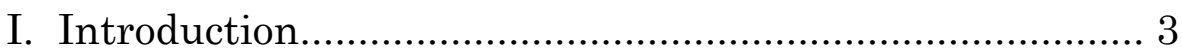

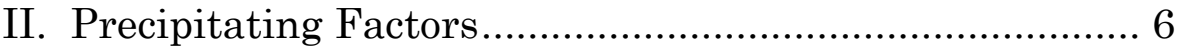

A. Pricing with Impunity .......................................... 7

B. The Public Funding Squeeze ................................ 10

1. A "Hidden Subsidy?"..................................... 11

2. The Impact of the COVID-19 Crisis ............... 15

C. Brittle Private Insurance ................................... 18

D. Health Insurance as a Co-Conspirator ................ 22

E. Retrospective Denial........................................... 24

III. Litigation As Strategy …............................................ 26

A. Before the Suit .................................................... 27

B. From Patient to Defendant .................................. 32

IV. A Signal of Catastrophic Failure................................... 38

A. Harm to Public Health ......................................... 39

1. Financial Toxicity ........................................... 40

2. Impact on Social Determinants of Health ....... 41

3. Deterring Future Care...................................... 42

B. Harm to Health Policy ........................................... 44

C. Harm to Health Finance....................................... 50

1. The Death of Moral Hazard .............................. 50

2. The Medical Necessity Quirk .......................... 52

D. Harm to Patient Trust......................................... 55

V. Banning Hospital Lawsuits.......................................... 57

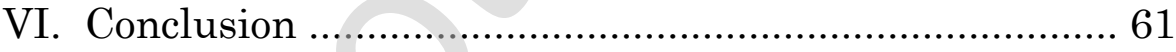


To be published in 73 Hastings L.J. _ (forthcoming 2021-22).

\title{
WHEN HOSPITALS SUE PATIENTS
}

\author{
Isaac D. Buck ${ }^{\dagger}$
}

"The biggest crime you can commit in America is being sick."

\section{INTRODUCTION}

Well before the day when a judge hears from a plaintiff hospital that is suing a patient it once cared for, the rickety structure of health care finance-made up of a series of decisions made by the government, hospitals, private payers, insurance companies, and even the patient's employer-picks unsurprising winners and unsuspecting losers. ${ }^{2}$ That path, complicated as it may seem, ultimately turns a patient who could not afford her surgery or emergency room visit into a defendant. ${ }^{3}$ From mission to adversary.

$\dagger$ Associate Professor, University of Tennessee College of Law; Juris Doctor, University of Pennsylvania Law School; Master of Bioethics, University of Pennsylvania; Bachelor of Arts, Miami University (Ohio). Thanks to the readers and commenters at the University of Missouri School of Law colloquium in the spring of 2021.

1 Laura Ungar, Heart Disease Bankrupted Him Once. Now He Faces Another \$10,000 Medical Bill, NPR, Sept. 25, 2020, available at https://www.npr.org/sections/health-shots/2020/09/25/916514499/heartdisease-bankrupted-him-once-now-he-faces-another-10-000-medical-bill (last accessed Jan. 12, 2021) (quoting 31-year-old Matthew Fentress of Louisville, Kentucky, who faces a second potential medical bankruptcy, following a surgical procedure known as an ablation in an effort to correct a heart arrhythmia).

2 Whether a hospital is qualified as a non-profit or not leads to major differences in the availability of patient financial assistance and the application of fair pricing rules, Professor Erin Fuse Brown refers to this game of chance as "fairness roulette." See Erin C. Fuse Brown, Fair Hospital Prices are Not Charity: Decoupling Hospital Pricing and Collection Rules from Tax Status, 53 U. LOUISVILLE L. REV. 509, 511, 538 (2016).

3 See e.g., Paul Kiel, From the E.R. to the Courtroom: How Nonprofit Hospitals Are Seizing Patients' Wages, ProPublicA, available at https://www.propublica.org/article/how-nonprofit-hospitals-are-seizingpatients-wages (last accessed Feb. 12, 2021):

Northwest first sued Keith and Katie Herie when they couldn't afford the $\$ 14,000$ bill for Katie's emergency appendectomy. While Northwest was seizing Keith Heries' [sic] pay for that suit, it sued him again over another hospital visit. Since 2006, the Heries have paid almost $\$ 20,000$ and still owe at least $\$ 26,000$, with interest mounting. 
To be published in 73 HASTINGS L.J. _ (forthcoming 2021-22).

It is this end scene-with a hospital garnishing the wages of a patient who doesn't know why she's been sued, ${ }^{4}$ or a corporate health system applying a lien to a property and taking nearly $\$ 40,000$ in proceeds of the sale of a house to pay a 13-year-old medical bill of a now-deceased relative, ${ }^{5}$ or even a university placing an enrollment hold on a college student's account for unpaid medical bills following a bout with lupus ${ }^{6}$ _ that seems more like a product of a disordered series of cascading failures than a well-planned financing system acting as designed. It is the grand finale, the final act, of the health care non-system's relentless melodrama.

The story is at once both simple and complicated. Americans know hospitals are highly expensive; of all contributors to costs in the United States, hospital expenditures are the largest. ${ }^{7}$ In 2019 , hospital expenditures

Id.

4 See Selena Simmons-Duffin, When Hospitals Sue for Unpaid Bills, It Can Be "Ruinous" For Patients, NPR, June 25, 2019, available at https://www.npr.org/sections/health-

shots/2019/06/25/735385283/hospitals-earn-little-from-suing-for-unpaid-

bills-for-patients-it-can-be-ruinous (last accessed Dec. 11, 2020):

On a sunny morning - the second Friday in June-the first defendant at court is a young woman, Daisha Smith, 24, who arrives early; she has just come off working an overnight shift at a group home for the elderly. She is here because the local hospital sued her for an unpaid medical bill-a bill she didn't know she owed until her wages started disappearing out of her paycheck.

5 See Jay Hancock, UVA Health Still Squeezing Money from Patients-By Seizing Their Home Equity, KaISER Health News, Oct. 19, 2020, available at https://khn.org/news/uva-health-property-lienspatient-medical-debt/ (last accessed Dec. 11, 2020):

UVA Health treated Hutchinson's brother for heart disease in the early $2000 \mathrm{~s}$. The unpaid bill was $\$ 24,868$. The system laid claim to their mother's home because he was one of her heirs. The claim is up to $\$ 38,000$ now, she said, because of interest charges. Hutchinson has been disputing it for more than a year.

$6 \quad$ See Jay Hancock and Elizabeth Lucas, "UVA Has Ruined Us:" Health System Sues Thousands of Patients, Seizing Paychecks and Putting Liens on Homes, WASH. Post, Sept. 11, 2019.

7 See Greg Rosalsky, How Non-Profit Hospitals Are Driving Up the Cost of Health Care, NPR, Oct. 15, 2019, available at 
To be published in 73 Hastings L.J. _ (forthcoming 2021-22).

reached nearly $\$ 1.2$ trillion, outpacing general growth patterns. ${ }^{8}$ From 2007 to 2014 , hospital inpatient prices rose 42 percent. ${ }^{9}$ And Americans-individually-are increasingly asked to foot the bill. ${ }^{10}$ In the face of these trends, hospitals have shifted from patient care to debt collection.

This move has an expected effect on American health care access: excess costs cause American patients to avoid care, because they are afraid to go to the hospital. ${ }^{11}$ This trend has been exacerbated by the COVID-19 pandemic; with millions of Americans out of work, more are now avoiding seeking necessary health care. ${ }^{12}$ During a pandemic, it seems that only in America would patients be avoiding the hospital-not due to a contagious and deadly pathogen, but because of the cost of American health care. ${ }^{13}$

As this article argues, when hospital sue patients, hospitals harm the public's health by deterring patients from seeking future care, and worsening patients' social determinants of health by increasing the likelihood of medical

https://www.npr.org/sections/money/2019/10/15/769792903/how-nonprofit-hospitals-are-driving-up-the-cost-of-health-care (last accessed Dec. $22,2020)$.

8 See NHE Fact Sheet, Centers for MedicARe AND MEdicAid SERviCES, Dec. 16, 2020, available at https://www.cms.gov/ResearchStatistics-Data-and-Systems/Statistics-Trends-and-

Reports/NationalHealthExpendData/NHE-Fact-Sheet (last accessed Dec. $22,2020)$.

$9 \quad$ See Zack Cooper et al., Hospital Prices Grew Substantially Faster Than Physician Prices for Hospital-Based Care in 2007-14, HeALTH AFFAIRS, Vol. 38, No. 2, Feb. 2019, available at https://www.healthaffairs.org/doi/abs/10.1377/hlthaff.2018.05424 (last accessed Dec. 22, 2020).

10 See Robin A. Cohen and Emily P. Zammitti, High-Deductible Health Plan Enrollment Among Adults Aged 18-64 With EmploymentBased Insurance Coverage, NCHS DATA BRIEF, HEALTH AND HUMAN Servs., Ctrs. For Disease Control And Prevention, Aug. 2018, available at https://www.cdc.gov/nchs/data/databriefs/db317.pdf (last accessed Dec. 12, 2020).

11 See Jeff Lagasse, More Than Half of Americans Have Avoided Medical Care Due to Cost, HealthCARe Finance News, Nov. 25, 2019, available at https://www.healthcarefinancenews.com/news/more-halfamericans-have-avoided-medical-care-due-cost (last accessed Dec. 22, 2020).

12 See Reed Abelson, Why People Are Still Avoiding the Doctor (It's Not the Virus), N.Y. Times, Jun. 16, 2020, available at https://www.nytimes.com/2020/06/16/health/coronavirus-insurancehealthcare.html (last accessed Dec. 22, 2020).

$13 \quad I d$. 
To be published in 73 HASTINGS L.J. _ (forthcoming 2021-22).

bankruptcy or a loss of housing or personal relationships. ${ }^{14}$ The lawsuits lay bare the failure of health policy, and the mismatch of the consumer paradigm to American health care. ${ }^{15}$ They also illustrate gaps and holes in health care financing, implicating quirks in how differently we think of medical necessity depending on the identity of the payer, and the flop of moral hazard. ${ }^{16}$ All of this, rather predictably, leads to a breakdown of patient trust, exacerbated and stressed by a devastating COVID-19 pandemic. ${ }^{17}$

Much of the scholarly focus in this space has heretofore been on whether hospitals are adequately treated as publicly minded entities and whether their non-profit tax status is defensible. This piece adds to this literature and broadens it, making the argument that hospitals' lawsuits against their patients-because of their devastating impacts-must be brought to an end. The impact of hospital lawsuits-whether from non-profit or for-profit entities-has dramatic and deleterious effects on interlocking layers of health care finance, delivery, and access. This piece argues that legal and ethical solutions, using other legal and ethical teaching, can be marshaled and recalibrated to put an end to these lawsuits.

The argument unfolds in four parts. In Part II, the precipitating factors - from market saturation, to the limits of public financing, to increasingly brittle private insuranceare presented. Part III documents the strategies that hospitals have adopted as they relate to litigating against former patients. In Part IV, the piece presents a typology of the cascading harms that result when hospitals sue patients, culminating in a destruction of patient trust in the health care system. Finally, Part V presents concluding thoughts on the way forward, with ideas on empowering law and ethics in an effort to bring this practice to a close.

\section{PRECIPITATING FACTORS}

From a systemic perspective, what forces these former patients and relatives of former patients to trek to the county courthouse as defendants is comprised of a tangled list of

\footnotetext{
14 See Discussion and accompanying notes, infra Part IV.A.

15 See Discussion and accompanying notes, infra Part IV.A.

16 See Discussion and accompanying notes, infra Part IV.C.

17 See Discussion and accompanying notes, infra Part IV.D.
} 
To be published in 73 HASTINGS L.J. _ (forthcoming 2021-22).

factors. Some of these factors are submerged, and, as such, are not readily ascertainable to the typical patient. ${ }^{18}$ Some are discoverable, but not obvious. Some, simply, are not salient. Others may be observable or expected, but-in recognition of the ineffective paradigm of health care as a consumer good and of patients as consumers ${ }^{19}$-it is not surprising that they still largely operate as surprises on American patients.

These related factors include both (1) the price inputs - the factors that lead to a hospital requiring more out of the patients it treats, and (2) a degradation of protections that once insulated patients from the full brunt of the cost of their health care. Specifically, four of these cost-impacting factors- (1) a consolidation of hospital markets and the resulting increasing prices across the country, (2) a decline of public funding, (3) the ineffectiveness of insurance to serve as a reliable cost control, and (4) a dissolution of health insurance protections, due to both employer cutbacks and anti-patient reforms-are explored more deeply below.

\section{A. Pricing with Impunity}

A discussion of hospital pricing must start with market power. $^{20}$ Over the last decade, health care markets have become increasingly saturated; by 2016, 90 percent of metropolitan areas "had highly concentrated hospital markets." 21 As the health care marketplace has consolidated and hospitals have secured increasing amounts of market

18 See Eric Lopez et al., How Much More Than Medicare Do Private Insurers Pay? A Review of the Literature, KAISER FAMILY Foundation, Apr. 15, 2020.

19 See, e.g., Allison K. Hoffman, 66 UCLA L. REV. 1926 (2019) (presenting the failure of market-based health care policies in American health care).

20 See Erin C. Fuse Brown, Resurrecting Health Care Rate Regulation, 67 HASTINGS L.J. 93 (2015) ("[V]ariations in hospital prices are dictated by market power of the hospital, not the hospital's costs, payer mix, quality, or whether it is a teaching hospital.").

21 Health Care Market Concentration Trends in the United States: Evidence and Policy Responses, The Commonwealth Fund, Sept. 6, 2017, available at https://www.commonwealthfund.org/publications/journalarticle/2017/sep/health-care-market-concentration-trends-united-states (last accessed Dec. 8, 2020). 
To be published in 73 HASTINGS L.J. _ (forthcoming 2021-22).

share, prices have risen. ${ }^{22}$ A familiar story follows-when hospitals consolidate, prices rise. ${ }^{23}$

A number of other studies demonstrate this. One has concluded that "prices at monopoly hospitals are 12 percent higher than those in markets with four or more rivals." 24 Another found, after looking at the highest-consolidated markets between 2010 and 2013, that "the price of an average hospital stay soared, with prices in most areas going up between 11 percent and 54 percent in the years afterward." 25 Other studies have concluded that mergers have led to price increases of 7 percent and 9 percent, respectively. ${ }^{26}$ In short, a "wide body of research has shown that provider consolidation leads to higher health care prices for private insurance." 27 With nearly 75 percent of hospital markets across the country deemed "highly concentrated," there has clearly been an impact on health care pricing. ${ }^{28}$

As applied to the prices of common and specific procedures, hospitals in concentrated markets have been found to charge 25 percent more for coronary angioplasties, 13 percent more for cardiac rhythm management device insertion, and nearly 20 percent more for total knee

22 See John B. Kirkwood, Buyer Power and Healthcare Prices, 91 Washington L. Rev. 253, 280 (2016) ("many retrospective studies have found that hospital mergers led to higher prices").

23 See Report to the Congress: Medicare Payment Policy, MedPAC, Mar. 2020, available at http://www.medpac.gov/docs/defaultsource/reports/mar20_entirereport_sec.pdf?sfvrsn=0 (last accessed Dec. 8, 2020).

24 Zack Cooper et al., The Price Ain't Right? Hospital Prices and Health Spending on the Privately Insured, 134 QUARTERLY J. ECON. 51 (Feb. 2019).

25 Reed Abelson, When Hospitals Merge to Save Money, Patients Often Pay More, N.Y. Times, Nov. 14, 2018, available at https://www.nytimes.com/2018/11/14/health/hospital-mergers-healthcare-spending.html (last accessed Dec. 8, 2020).

26 See Leemore Dafny, et al., The Price Effects of Cross-Market Hospital Mergers, NBER Working Paper Series, Oct. 2018, available at https://www.nber.org/system/files/working_papers/w22106/w22106.pdf (last accessed Dec. 8, 2020).

27 Karyn Schwartz et al., What We Know About Provider Consolidation, KAISER FAMILY Foundation, Sept. 2, 2020, available at https://www.kff.org/health-costs/issue-brief/what-we-know-aboutprovider-consolidation/ (last accessed Dec. 8, 2020).

28 See Allison Inserro, Nearly 75\% of US Hospital Markets Highly Concentrated, HCCI Report Shows, AJMC, Sept. 17, 2019, available at https://www.ajmc.com/view/nearly-75-of-us-hospital-markets-highlyconcentrated-hcci-report-shows (last accessed Dec. 11, 2020). 
To be published in 73 Hastings L.J. _ (forthcoming 2021-22).

replacements. ${ }^{29}$ They charge 24 percent more for total hip replacements, 19 percent more for lumbar spine fusions, and 23 percent more for cervical spine fusions. ${ }^{30}$ To make matters worse, the foregoing belief that one of the main arguments in favor of hospital consolidation - that it improves quality-has recently been called into serious question. ${ }^{31}$

That hospital consolidation results in higher health care prices is not a surprise. As in any other market, hospitals with powerful leverage-and particularly hospitals that are part of systems with large market shares ${ }^{32}$ in markets-have the ability to negotiate higher rates with payers than those that do not. 33

In an effort to combat the worst effects of market consolidation and increase price transparency for patients, a new HHS rule now requires hospitals to publicly disclose and provide patients "in a consumer-friendly manner" negotiated rates for a list of hundreds of health care services. ${ }^{34}$ The American Hospital Association (AHA) sued HHS to enjoin its

29 See James C. Robinson, Hospital Market Concentration, Pricing, and Profitability in Orthopedic Surgery and Interventional Cardiology, 17 AM. J. MANAGED CARE 241 (2011).

30 See id.

31 See Austin Frakt, Hospital Mergers Improve Health? Evidence Shows the Opposite, N.Y. TIMES, Feb. 11, 2019, available at https://www.nytimes.com/2019/02/11/upshot/hospital-mergers-hurthealth-care-quality.html (last accessed Dec. 8, 2020).

32 See Dave Barkholz, Data Suggest New York Hospital Prices Depend on Leverage, Not Quality, Modern HealthCARE, Dec. 19, 2016, available at

https://www.modernhealthcare.com/article/20161219/NEWS/161219910/ data-suggest-new-york-hospital-prices-depend-on-leverage-not-quality (last accessed Dec. 9, 2020) ("Hospitals with bargaining muscle in New York are getting paid 1.5 to 2.7 times as much for care by insurers as the lowest-priced hospitals in the same market, a new study shows.").

33 Interestingly but unsurprisingly, recent studies have shown-at least as it relates to doctors and other providers-that insurance companies with larger market share are better able to demand lower prices than those with smaller market share. See Eric T. Roberts et al., Market Share Matters: Evidence of Insurer and Provider Bargaining Over Prices, HEALTH AFFAIRS, Jan. 2017, available at https://www.healthaffairs.org/doi/full/10.1377/hlthaff.2016.0479 (last accessed Dec. 11, 2020).

34 See Trump Administration Announces Historic Price Transparency Requirements to Increase Competition and Lower Healthcare Costs for All Americans, U.S. Health and Human Servs., Nov. 15, 2019, available at https://www.hhs.gov/about/news/2019/11/15/trumpadministration-announces-historic-price-transparency-and-lowerhealthcare-costs-for-all-americans.html (last accessed Dec. 11, 2020). 
To be published in 73 HASTINGS L.J. _ (forthcoming 2021-22).

implementation, ${ }^{35}$ but was unsuccessful, ${ }^{36}$ and the rule took effect on January 1, 2021. ${ }^{37}$

\section{B. The Public Funding Squeeze}

The publicly-funded programs of Medicare and Medicaid are becoming less profitable-and perhaps, not at all profitable-for hospitals. As a result, privately funded insurance plans make up an increasing share of hospitals' revenue. ${ }^{38}$ A recent study found that moving all payers to Medicare rates would cause hospital revenues to plummet 35 percent. ${ }^{39}$ Lower Medicaid reimbursement rates have a major negative impact on access to health care for Medicaid beneficiaries. ${ }^{40}$

The AHA has estimated that combined underpayments - that is, the amount by which payment from the public programs of Medicare and Medicaid was less than hospitals' costs—totaled $\$ 76.6$ billion in $2018 .{ }^{41}$ The majority

35 See Robert King, Appeals Court Skeptical of AHA in Lawsuit Over HHS Price Transparency Rule, Fierce HealthCARe, Oct. 15, 2020, available at https://www.fiercehealthcare.com/hospitals/appeals-courtskeptical-aha-lawsuit-over-hhs-price-transparency-rule (last accessed Dec. 11, 2020) (describing the appellate judges hearing the case as "very skeptical of the hospital industry's arguments").

$36 \quad$ See Sarah Kliff and Margot Sanger-Katz, Hospitals Sued to Keep Prices Secret. They Lost., N.Y. TIMES, Jun. 23, 2020, available at https://www.nytimes.com/2020/06/23/upshot/hospitals-lost-pricetransparency-lawsuit.html (last accessed Feb. 10, 2021).

37 See Sarah O'Brien, CNBC, Jan. 5, 2021, available at https://www.cnbc.com/2021/01/05/hospitals-must-now-post-their-pricesonline-how-consumers-may-benefit.html (last accessed Feb. 11, 2021).

38 See Michael E. Chernew et al., Wide State-Level Variation in Commercial Health Care Prices Suggests Uneven Impact of Price Regulation, 39 Health AFF. No. 5, May 2020, available at https://www.healthaffairs.org/doi/full/10.1377/hlthaff.2019.01377 (last accessed Dec. 11, 2020) (finding that "average hospital revenue would fall about 35 percent if commercial prices were limited to Medicare rates, but this would vary widely by state").

39 Id.

40 See Alison Borchgrevink, et al., The Effects of Medicaid Reimbursement Rates on Access to Dental Care, NATIONAL ACADEMY FOR STATe Health Policy, Mar. 2008, at 14, available at https://www.nashp.org/wp-

content/uploads/2009/03/CHCF_dental_rates.pdf (last accessed Dec. 22, 2020). (noting that provider participation in Medicaid substantially increased following dental rate increases).

41 See Fact Sheet: Underpayment by Medicare and Medicaid, Jan. 2020, AMERICAN HOSPITAL ASS'N, available at 
To be published in 73 HASTINGS L.J. _ (forthcoming 2021-22).

of this was due to underpayments from the Medicare program, but both programs failed to reimburse hospitals at cost. ${ }^{42}$ Seemingly bucking this trend, in 2020, Medicare made its highest reimbursement rate increases in yearsamounting to a $\$ 4.67$ billion increase in payments to hospitals as part of its inpatient prospective payment system update. ${ }^{43}$ But it is still unclear how this increase will impact the overall Medicare reimbursement for hospitals.

And this was before the COVID-19 pandemic. When New York was enduring the worst COVID-19 numbers in the world in the spring of $2020,{ }^{44}$ the $\$ 400$ million cut that the New York Medicaid program was planning to make in payments to its public hospitals was still making headlines. ${ }^{45}$ The cut was later delayed.46 Both of these topics-the growing gaps between public and private payers, and the exacerbation of these trends by the COVID-19 pandemic-are laid out in more detail below.

\section{A "Hidden Subsidy?"}

A number of recent studies have shown disparate reimbursement rates between public and private payers for

https://www.aha.org/system/files/media/file/2020/01/2020-Medicare-

Medicaid-Underpayment-Fact-Sheet.pdf (last accessed Dec. 8, 2020).

$42 \quad I d$.

43 See Alex Kacik, Not-For-Profit Hospitals Stabilized by Medicare Pay Raise, DSH Cut Delays, Modern HealthCARE, Dec. 9, 2019, available at https://www.modernhealthcare.com/providers/not-profit-hospitals-

stabilized-medicare-pay-raise-dsh-cut-delays (last accessed Dec. 12, 2020) (noting that $\$ 4$ billion in Medicaid DSH payment cuts were delayed into late 2020).

44 See Jennifer Millman, New York Has Most COVID-19 Cases in World, Deaths Top 7k as Curve Starts to Flatten, NBC NEW YoRK, Apr. 10, 2020, available at https://www.nbcnewyork.com/news/local/new-york-hasmost-covid-19-cases-in-globe-cuomo-warns-of-more-death-even-as-curveflattens/2366721/ (last accessed Dec. 11, 2020).

45 See Luis Ferre-Sadurni and Jesse McKinley, N.Y. Hospitals Face $\$ 400$ Million in Cuts Even As Virus Battle Rages, N.Y. TIMES, Mar. 30, 2020 , available

https://www.nytimes.com/2020/03/30/nyregion/coronavirus-hospitalsmedicaid-budget.html (last accessed Dec. 7, 2020)

46 See Michael Greenberg, The Costs of Cuomo's Cuts, New YorK REVIEW, Jul. 2020, available at https://www.nybooks.com/articles/2020/07/02/andrew-cuomo-budget-cuts/ (last accessed Dec. 7, 2020) (noting that "the $\$ 400$ million decrease in state Medicaid payments to public hospitals has been delayed, mainly because it threatened New York's eligibility for federal coronavirus funds"). 
To be published in 73 HASTINGS L.J. _ (forthcoming 2021-22).

hospitals. ${ }^{47}$ Hospital reimbursement rates for private payers, on average, are close to 200 percent of what Medicare pays. ${ }^{48}$ For inpatient services, private insurance rates are about 189 percent of what Medicare pays. ${ }^{49}$ And for outpatient services, the differences are even more stark-with hospitals earning from private payers about 264 percent of what Medicare pays. ${ }^{50}$ These disparities show up in all sorts of medical procedures:

For a patient's knee replacement, Medicare will pay a hospital $\$ 17,000$. The same hospital can get more than twice as much, or about $\$ 37,000$, for the same surgery on a patient with private insurance. Or take another example: One hospital would get about $\$ 4,200$ from Medicare for removing someone's gallbladder. The same hospital would get $\$ 7,400$ from commercial insurers. ${ }^{51}$

Based on an extensive literature review, the differences among reimbursement rates for hospitals-and particularly between private payers and Medicare-are more striking than the differences between physician services. ${ }^{52}$

The gap between private payers and public payers appears to be widening, leading to real concerns among health care providers about the impact of "Medicare for All" proposals. ${ }^{53}$ Indeed, there may be real concerns raised about the adequate funding of single payer proposals, particularly because they sweep away private insurance reimbursement for hospitals, eliminating this cross-subsidy, causing dislocation to the reimbursement structure. ${ }^{54}$ $\begin{aligned} 47 & \text { See Lopez, supra note } 18 . \\ 48 & \text { Id. } \\ 49 & \text { Id. } \\ 50 & \text { Id. } \\ 51 & \text { Reed Abelson, Hospitals Stand to Lose Billions } \text { Under "Medicare } \\ \text { for } & \text { All," N.Y. TimES, Apr. 21, 2019, available at }\end{aligned}$ https://www.nytimes.com/2019/04/21/health/medicare-for-all-

hospitals.html (last accessed Dec. 7, 2020).

52 See Lopez, supra note 18.

$53 \quad$ See Abelson, supra note 51.

54 See Isaac D. Buck, The Meaning of "Medicare-For-All," 20 Hous. J. HEALTH L. \& Pol'y 159, 189 (2020) ("'what makes Medicare so efficient now is that providers continue to participate in the Medicare program and 
To be published in 73 Hastings L.J. _ (forthcoming 2021-22).

Similarly, hospitals have been hostile to proposals to lower the Medicare eligibility age to 60.55 Even though the proposal to lower Medicare eligibility is politically popular, "[h]ospitals fear adding millions of people to Medicare will cost them billions of dollars in revenue," largely because the difference in reimbursement rates between Medicare and private insurance plans. ${ }^{56}$ Other policy interventions under consideration - such as a construction within the ACA of the so-called public option ${ }^{57}$ - "would give more people access to coverage with lower payments rates and premiums, while also resulting in lower revenues for health care providers." 58

These findings - that private payers are paying a lot more than public payers - coincide with a trend of decreasing Medicare margins for hospitals.59 According to a Kaiser analysis, hospitals experienced a negative Medicare margin of about nine percent in 2018, which is down from negative margins closer to five percent from 2010-2014.60 Negative margins even exist for the more efficiently run hospitals, as they experienced a negative two percent margin in 2017 and

do not have to clamor for increasing reimbursement because they receive such substantial reimbursements from private insurance").

55 See Phil Galewitz, Biden Wants to Lower Medicare Eligibility Age to 60, But Hospitals Push Back, NPR, Nov. 11, 2020, available at https://www.npr.org/sections/health-shots/2020/11/11/933522346/bidenwants-to-lower-medicare-eligibility-age-to-60-but-hospitals-push-back (last accessed Dec. 11, 2020).

$56 \quad I d$.

57 See Margot Sanger-Katz, The Difference Between a "Public Option" and "Medicare for All"? Let's Define Our Terms, N.Y. Times, Feb. 19, 2019, available at https://www.nytimes.com/2019/02/19/upshot/medicare-for-all-healthterms-sanders.html (last accessed Dec. 21, 2020) (defining such reform plans as making available the option for "middle-income, working-age adults to choose a public insurance plan-like Medicare or Medicaidinstead of a private plan").

58 Lopez, supra note 18.

59 See Susan Morse, Efficient Hospitals Operate on -2\% Margins in Medicare Payments, MedPAC Reports, HealthCare Finance, Mar. 15, 2019, available

https://www.healthcarefinancenews.com/news/efficient-hospitals-

operate-2-margins-medicare-payments-medpac-reports (last accessed Dec. 7, 2020) (quoting MedPAC [Medicare Payment Advisory Commission] Executive Director Dr. James Matthews as saying, "Medicare margins in the hospital sector have been negative for some time now.").

60 See Lopez, supra note 18. 
To be published in 73 HASTINGS L.J. _ (forthcoming 2021-22).

2018, respectively. ${ }^{61}$ This is down from a positive two percent margin experienced between 2011 and 2013. ${ }^{62}$ Numbers from the AHA have demonstrated the same trends, and, based on numbers from 2016, Medicare "pays hospitals about 87 cents for every dollar of their costs, compared with private insurers that pay $\$ 1.45 . " 63$

That public payers pay less than private payers is not in real dispute. And although it seems as though a public funding squeeze would result in more pressure on private payers, data suggests that there is an important caveat to mention here.

Specifically, recent data suggests that mergers are causing higher profits, not specifically that low Medicare rates are causing higher private payer rates and mergers. ${ }^{64}$ In a 2020 report, MedPAC noted that "[s]ome industry stakeholders have posited that low Medicare margins are a driver of mergers and acquisitions as hospitals seek to maintain their profitability by increasing efficiency and increasing their ability to extract higher payments from commercial payers."65 Nonetheless, "hospital profits on nonMedicare patients increased not only enough to offset all Medicare losses, but by a greater amount such that hospital all-payer profit margins are higher now than they were in the prior 20 years." 66

Indeed, according to MedPAC, "[b]ecause all-payer profits were highest when Medicare margins were lowest, we can infer that the increase in commercial prices was not done purely to offset Medicare losses."67 In short, hospitals' price increases were too high to tell a clear causal story of Medicare cutbacks leading to private insurance rate increases. Other studies have echoed the finding that high hospital prices are not correlated with high numbers of Medicare and Medicaid patients; in fact, a study of New York hospitals concluded that hospitals with higher Medicare and Medicaid populations actually charged private payers less. ${ }^{68}$ Publicly-funded subsidies, and, as an example, disproportionate share funding

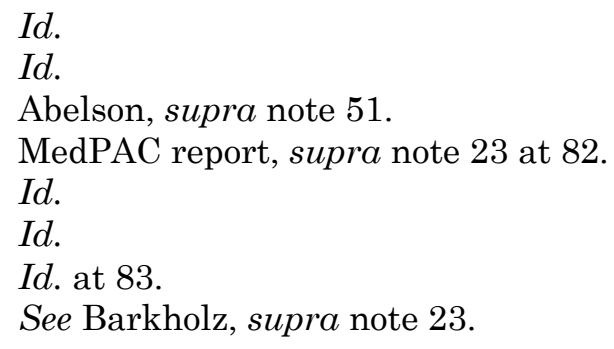


To be published in 73 HASTINGS L.J. _ (forthcoming 2021-22).

(DSH), provides a submerged funding stream for hospitals; cuts that were required under the ACA have been delayed. 69 Currently, the scheduled DSH cuts amount to $\$ 44$ billion by $2025 . .^{70}$

\section{The Impact of the COVID-19 Crisis}

Indeed, these funding trends were well in place before the COVID-19 public health emergency. But in 2020, the pandemic increased enrollment in Medicaid, which strained state budgets further. ${ }^{71}$ Between February and July, more than four million people were estimated to have been added to the Medicaid rolls across the country, ${ }^{72}$ amounting to an enrollment growth of more than five percent. 73 Specifically, Medicaid enrollment grew more than ten percent in Nevada, Florida, Oklahoma, Indiana, Minnesota, Missouri, Utah, and Kentucky. ${ }^{74}$ Recent expectations show that Medicaid enrollment is expected to increase more than eight percent in FY 2020-21.75

This is happening at the same time that states have been concerned about a rapid drop in tax revenue due to the

69 See Kacik, supra note 32.

70 See Rich Daly, Hospitals Get Relaxed Medicare Repayment Terms, Short Delay of DSH Cut in Federal Funding Bill, HEALTHCARE FinanCIAL MANAGEMENT ASS'N., Oct. 6, 2020, available at https://www.hfma.org/topics/news/2020/10/hospitals-get-relaxedmedicare-repayment-terms--short-delay-of-d.html (last accessed Dec. 11, 2020).

71 See Stephanie Armour, Medicaid Enrollment Surge During Pandemic Leaves States Looking for Cost Cuts, WALl ST. J., Nov. 27, 2020, available at https://www.wsj.com/articles/medicaid-enrollment-surgeduring-pandemic-leaves-states-looking-for-cost-cuts-11606489203 (last accessed Dec. 7, 2020).

72 See Gaby Galvin, Without Guarantee of Additional COVID-19 Aid, State Medicaid Directors Warn of Painful Cuts Ahead, MoRning Consult,

Sept. 17, 2020, available at https://morningconsult.com/2020/09/17/medicaid-fmap-funding-statescoronavirus/ (last accessed Dec. 7, 2020). Kentucky is estimated to have added 17.2 percent to its Medicaid enrollment. $I d$.

73 See Rich Daly, More Medicaid Programs are Planning Inpatient Hospital Payment Cuts, HFMA, Oct. 15, 2020, available at https://www.hfma.org/topics/news/2020/10/more-medicaid-programs-areplanning-inpatient-hospital-payment-c.html (last accessed Dec. 8, 2020).

$74 \quad$ See Galvin, supra note 72.

75 See Armour, supra note 71. 
To be published in 73 Hastings L.J. _ (forthcoming 2021-22).

pandemic. ${ }^{76}$ While the most dire projections did not pan out for FY $2020^{77}$ largely due to assistance from the federal government and the fact that wealthy residents have not been impacted as severely by the pandemic, ${ }^{78}$ states have nonetheless imposed dramatic spending cuts. ${ }^{79}$ Most expect substantial revenue declines lasting well into FY 2021 and FY 2022.80 With this eye toward the future, President Biden's American Rescue Plan seeks to bolster state funding, particularly with an eye toward state-funded education. ${ }^{81}$

A major part of state budgets, adequate funding for the Medicaid program also continues to be a concern. As part of the Families First Coronavirus Response Act, the federal government bolstered FMAP percentages by 6.2 percent in March. ${ }^{82}$ This funding bump is to remain as long as the public

76 See Amanda Albright, States See $\$ 31$ Billion of Taxes Disappear Due to Covid Recession, BlOOMBERG, Oct. 13, 2020, available at https://www.bloomberg.com/news/articles/2020-10-13/states-see-31-

billion-of-taxes-disappear-due-to-covid-recession (last accessed Dec. 7, 2020).

77 Editorial Board, State Tax Revenue Rebound, WaLl ST. J., Nov. 16, 2020, available at https://www.wsj.com/articles/state-tax-revenuerebound-11605568517 (last accessed Dec. 7, 2020).

78 See Emily Badger et al., Why Some States Are Seeing Higher Revenue Than Expected Amid Job Losses, N.Y. Times, Dec. 18, 2020, available at https://www.nytimes.com/2020/12/18/upshot/pandemicsurprising-state-revenue.html (last accessed Dec. 21, 2020).

79 See, e.g., James Anderson, Colorado Governor Unveils State Budget Plan Amid Pandemic, AP NEws, available at https://apnews.com/article/technology-pandemics-virus-outbreak-

colorado-jared-polis-950b5a2be2db5342e9d872d933b2f6dc (last accessed Dec. 7, 2020) ("In this year's coronavirus-shortened session, lawmakers cut $\$ 3.3$ billion from the $\$ 13$ billion general fund for the fiscal year that began July 1. Cuts included $\$ 621$ million from K-12 funding and $\$ 598$ million from higher education.”).

80 States Grappling with Hit to Tax Collections, CENTER ON BUDGET AND POLICY PRIORITIES, Nov. 6, 2020, available at https://www.cbpp.org/research/state-budget-and-tax/states-grapplingwith-hit-to-tax-collections (last accessed Dec. 7, 2020) (with most state estimates projecting between a 5 and 20 percent decline in the preCOVID-19 revenue projections for FY 2021 and FY 2022).

81 President Biden Announces American rescue Plan, The White House, Jan. 20, 2021, available at https://www.whitehouse.gov/briefingroom/legislation/2021/01/20/president-biden-announces-american-rescueplan/ (last accessed Feb. 3, 2021). The plan also seeks to bump the federal government's FMAP percentage for Medicaid for administering COVID vaccinations. Id.

82 See Aviva Aron-Dine et al., With Need Rising, Medicaid Is At Risk for Cuts, Center for Budget And Policy Priorities, Jul. 22, 2020, 
To be published in 73 Hastings L.J. _ (forthcoming 2021-22).

health emergency declaration is in place ${ }^{83}$ and has helped states that have faced budgetary shortfalls ${ }^{84}$ to defer Medicaid cuts. ${ }^{85}$ Congress has also used this money to incentivize states to maintain coverage levels and prevent cuts to coverage levels for current beneficiaries. ${ }^{86}$

Nonetheless, in response to the COVID-19 crisis, some states have made the decision to cut coverage and/or have suspended Medicaid coverage expansion plans. ${ }^{87}$ Nevada, for example, passed a six percent Medicaid rate reduction, hoping to save the state more than $\$ 50$ million. ${ }^{88}$ Wyoming cut reimbursement rates for "most providers" by 2.5 percent. 89 And other states' Medicaid programs, like Ohio's, are facing billions of dollars in shortfalls. ${ }^{90}$

On top of the budgetary shortfalls, job losses as a result of the COVID-19 public health emergency are also likely to

available at https://www.cbpp.org/research/health/with-need-risingmedicaid-is-at-risk-for-cuts (last accessed Dec. 6, 2020).

$83 \quad I d$.

84 Id.; States Are Broke and Many Are Eyeing Massive Cuts. Here's How Yours Is Doing, NPR, Aug. 3, 2020, available at https://www.npr.org/2020/08/03/893190275/states-are-broke-and-manyare-eyeing-massive-cuts-heres-how-yours-is-doing (last accessed Dec. 6, 2020); Scott Cohn, Cuts to Basic Services Loom As Coronavirus Ravages Local Economies and Sends States Into Fiscal Crisis, CNBC, Jul. 7, 2020, available at https://www.cnbc.com/2020/07/07/states-in-fiscal-crisis-cutsto-basic-services-loom-due-to-pandemic.html (last accessed Dec. 7, 2020).

85 See Aron-Dine, supra note 82.

86 See id.

87 See id. (noting that Nevada has "adopted a 6 percent across-theboard cut in payment rates for hospitals, physicians, behavioral health providers, and long-term support services providers such as nursing homes").

88 See Megan Messerly, Medicaid Pushes Ahead with 6 Percent Rate Decrease Proposed During Budget-Slashing Special Session, THE NEVADA INDEPENDENT, Aug. 13, 2020, available at https://thenevadaindependent.com/article/medicaid-pushes-ahead-with6-percent-rate-decrease-proposed-during-budget-slashing-special-session (last accessed Dec. 7, 2020). See also John Sadler, Medicaid, Health, Education Bear Brunt of Nevada Lawmakers' Cuts, LAs VEGAS Sun, Jul. 19, 2020, available at https://lasvegassun.com/news/2020/jul/19/medicaidhealth-budgets-bear-brunt-of-nevada-lawma/ (last accessed Dec. 7, 2020).

89 See Galvin, supra note 72.

90 See Catherine Candisky, Ohio Medicaid Caseload Soars Due to COVID-19, But Now Program Faces Budget Gap of Billions, THE Columbus DisPatch, Nov. 6, 2020, available at https://www.dispatch.com/story/news/healthcare/2020/11/06/budgetshortfall-may-cause-cuts-ohios-tax-funded-medicaid-program-poordisabled-because-covid/6165391002/ (last accessed Dec. 7, 2020). 
To be published in 73 Hastings L.J. _ (forthcoming 2021-22).

strain hospital expenditures further. With millions of workers losing their employment and their accompanying private health insurance, hospitals face the prospect of an increasing percentage of uncompensated care due to the pandemic - at the same time that they face a surge in the number of people needing health care, including heroic measures to save their lives. ${ }^{91}$ A number of those will move from private insurance coverage to Medicaid, likely shrinking the hospital's revenue for their care..$^{92}$ A recent study estimates that, as of June of 2020, nearly 15 million Americans had lost employer-based coverage since the beginning of the pandemic. ${ }^{93}$ This includes an estimated 7.7 million former workers and their nearly seven million dependents. ${ }^{94}$

\section{Brittle Private Insurance}

Private health insurance-once a reliable protective against financial ruin following a health care emergencycontinues to disintegrate. Specifically, many workers are seeing their employer-based health insurance-for years, the gold standard for protecting workers' and their families' pocketbooks and health status-rapidly unwinding. A 2020 Kaiser survey showed an annual premium increase of four

91 See, e.g., Richard Harris, Advances in ICU Care Are Saving More Patients Who Have COVID-19, NPR, Sept. 20, 2020, available at https://www.npr.org/sections/healthshots/2020/09/20/914374901/advances-in-icu-care-are-saving-morepatients-who-have-covid-19 (last accessed Dec. 11, 2020).

92 See Schwartz et al., supra note 14:

KFF has estimated that by early May 2020, nearly 27 million people were at risk of losing employer-sponsored coverage due to a job loss. About half of those individuals were estimated to be eligible for Medicaid and about 30\% were estimated to be eligible for subsidized marketplace coverage. This shift from employer coverage to Medicaid alone will lead to lower revenues for providers, because employer-sponsored insurance tends to reimburse at much higher rates than Medicaid.

93 See Ann Carrns, Even With Challenges of Pandemic, Health Benefits May Not Change Much, N.Y. Times, Oct. 16, 2020, available at https://www.nytimes.com/2020/10/16/your-money/health-insurance-costdeductibles.html (last accessed Dec. 11, 2020).

$94 \quad I d$. 
To be published in 73 Hastings L.J. _ (forthcoming 2021-22).

percent, year over year, for both single individual health insurance and for those covering their families. ${ }^{95}$ This outpaced wages, as those increased 3.4 percent in 2020.96 Remarkably, according to a survey, the average premium for coverage for a family has now grown 22 percent over five years and 55 percent over ten years. ${ }^{97}$ The mean annual cost for a health insurance premium for a family was more than $\$ 21,000$ in $2020 .{ }^{98}$

Cost sharing also continues to increase for employees. The average deductible for a single worker was $\$ 1,644$ in 2020, which has increased 25 percent over the last five years and 79 percent over ten years. ${ }^{99}$ Now 83 percent of workers have a deductible, and the average deductible among all covered workers amounts to $\$ 1,364$, up from $\$ 1,077$ in 2015 and $\$ 646$ in 2010.100

This continued a trend: in its 2019 survey, Kaiser found that from 2009 to 2019, while wages for Americans rose 26 percent, deductibles rose 162 percent. 101 Even worse, it seems that the increased premiums required from employees disproportionately impact lower-wage workers. ${ }^{102}$ This is on

95 See 2020 Employer Health Benefits Survey, KAISER FAMILY Foundation, Oct. 8, 2020, available at https://www.kff.org/reportsection/ehbs-2020-summary-of-findings/ (last accessed Dec. 11, 2020).

96 See Alicia Adamczyk, Health Insurance Premiums Increased More Than Wages This Year, CNBC, Sept. 26, 2019, available at https://www.cnbc.com/2019/09/26/health-insurance-premiums-increasedmore-than-wages-this-year.html (last accessed Dec. 11, 2020).

$97 \quad$ See 2020 Employer Health Benefits Survey, supra note 77.

98 See id. See also Reed Abelson, Workers with Health Insurance Face Rising Out-of-Pocket Costs, N.Y. Times, Oct. 8, 2020, available at https://www.nytimes.com/2020/10/08/health/health-insurance-premiumsdeductibles.html (last accessed Dec. 12, 2020).

$99 \quad$ See 2020 Employer Health Benefits Survey, supra note 65.

$100 \quad I d$.

101 See Benchmark Employer Survey Finds Average Family Premiums Now Top $\$ 20,000$, KAISER FAMILY FoundATION, available at https://www.kff.org/health-costs/press-release/benchmark-employer-

survey-finds-average-family-premiums-now-top-20000/ (last accessed Dec. 11, 2020) ("The single biggest issue in health care for most Americans is that their health costs are growing much faster than their wages are,' KFF President and CEO Drew Altman said. 'Costs are prohibitive when workers making $\$ 25,000$ a year have to shell out $\$ 7,000$ a year just for their share of family premiums."').

102 See Michelle Andrews, As Health Care Costs Rise, Workers At LowWage Firms May Pay a Larger Share, Kaiser Health News, Sept. 25, 2019, available at https://khn.org/news/health-care-costs-employersurvey-workers-at-lower-wage-firms-may-have-higher-costs/ (last 
To be published in 73 Hastings L.J. _ (forthcoming 2021-22).

top of the fact that "fewer workers at companies with large numbers of lower-wage workers were eligible for coverage in the first place."103

At the same time premiums and deductibles are rising, ${ }^{104}$ an increasing number of Americans have enrolled in high-deductible health plans (HDHPs), ${ }^{105}$ meaning that as the raw costs of insurance are increasing, and the percentage of costs for which workers are responsible is growing, now the number of people who are responsible for the growing percentage of those costs is also rising. The CDC has found that more than 43 parent of non-elderly adults were enrolled in HDHPs in 2017.106 Compare this to ten years before: according to CDC data, enrollment in HDHPs in 2007 was only 14.8 percent. ${ }^{107}$

Now more than one in five employer-based health insurance beneficiaries have plans with deductibles over $\$ 3,000$ for individuals and $\$ 5,000$ for families. ${ }^{108}$ Besides

accessed Jan. 27, 2021) ("People wat companies with large numbers of lower-wage employees faced bigger deductibles for single coverage and were asked to pony up a larger share of their incomes to pay premiums than those at firms with fewer people with low earnings").

103 Id.

104 See Reed Abelson, Employer Health Insurance Is Increasingly Unaffordable, Study Finds, N.Y. TIMEs, Sept. 30, 2019, available at https://www.nytimes.com/2019/09/25/health/employer-health-insurancecost.html (last accessed Dec. 22, 2020) ("Many businesses have opted to increase deductibles instead of premiums.").

105 See Allison Inserro, Enrollment in High-Deductible Health Plans Continues to Grow, AM. J. MANAGED CARE, Aug. 9, 2018, available at https://www.ajmc.com/view/enrollment-in-highdeductible-health-planscontinues-to-grow (last accessed Feb. 3, 2021).

106 See Robin A. Cohen and Emily P. Zammitti, High-Deductible Health Plan Enrollment Among Adults Aged 18-64 With EmploymentBased Insurance Coverage, NCHS DATA BRIEF, HEALTH AND HUMAN Servis., Ctrs. for Disease Control and Prevention, Aug. 2018, available at https://www.cdc.gov/nchs/data/databriefs/db317.pdf (last accessed Dec. 12, 2020).

107 See Robin A. Cohen and Emily P. Zammitti, High-Deductible Health Plan Enrollment Among Adults Aged 18-64 With EmploymentBased Insurance Coverage, Key Findings, NCHS Data Brief No. 317, Aug. 2018, available

at https://www.cdc.gov/nchs/products/databriefs/db317.htm (last accessed Dec. 11, 2020).

108 See Aimee Picchi, Higher Health Insurance Deductibles a Sickening Trend for Americans, CBS NEws, Jun. 13, 2019, available at https://www.cbsnews.com/news/high-health-insurance-deductibles-asickening-trend-thats-causing-financial-hardship/ (last accessed Dec. 11, 2020). 
To be published in 73 Hastings L.J. _ (forthcoming 2021-22).

sticking individuals with additional out-of-pocket expenditures following their care, high deductibles can also deter individuals from seeking needed care, 109 and even impact employment and professional decision-making, ${ }^{110}$ leading to the traditional economic wisdom supporting their inclusion in health insurance plans to be questioned. ${ }^{111}$

As could be predictable, high deductibles lead to nonpayment by patients. ${ }^{112}$ According to a 2016 analysis, only 36 percent of patients with a deductible of more than $\$ 5,000$ were likely to pay some portion of their health bills. ${ }^{113}$ And while the number of uninsured Americans has dropped over the last ten years, ${ }^{114}$ the number of insured Americans who are unable to afford doctor's visits, over the last twenty years, has risen from just over seven percent to 11.5 percent. 115 Health insurance coverage rates may have increased, but the insulation of that coverage has shrunk at the same time.

Not only is employer-based insurance becoming less durable, but the COVID-19 pandemic could have dramatic effects on America's improving insurance rate. Throughout 2020, surging unemployment suggested a downward trend of

109 Id. ("Lianna Patch, a 29-year-old copywriter in New Orleans, said her $\$ 6,500$ individual deductible causes her to put off visits to her physician.").

110 See Reed Abelson, Employer Health Insurance Is Increasingly Unaffordable, Study Finds, N.Y. Times, Sept. 30, 2019, available at https://www.nytimes.com/2019/09/25/health/employer-health-insurancecost.html (last accessed Dec. 22, 2020).

111 See Christopher T. Robertson, Exposed: Why Health Insurance Is Incomplete And What CAN Be Done About It (Harvard Univ. Press, 2019).

112 See Andrews, supra note 102.

113 Id.

114 See Jennifer Tolbert et al., Key Facts About the Uninsured Population, KAISER FAMILY Foundation, Nov. 6, 2020, available at https://www.kff.org/uninsured/issue-brief/key-facts-about-the-uninsuredpopulation/ (last accessed Dec. 16, 2020) (the uninsured rate has dropped from 17.3 percent in 2009 to 10.9 percent in 2019).

115 See Lisa Rapaport, Despite Insurance Gains, More People in the U.S. Can't Afford Doctors, REUTERS, Jan. 27, 2020, available at https://www.reuters.com/article/us-health-physicians-costs/despiteinsurance-gains-more-people-in-the-u-s-cant-afford-doctors-

idUSKBN1ZQ2FA (last accessed Dec. 15, 2020) ("Out-of-pocket costs made doctors too expensive for the uninsured, but costs also kept people with coverage from seeing physicians even when they had chronic medical conditions requiring regular checkups."). 
To be published in 73 HASTINGS L.J. _ (forthcoming 2021-22).

employer-based insurance. ${ }^{116}$ Aggravated by the pandemic, employers are likely to be eyeing major cuts to health insurance for their workers in $2021 .{ }^{117}$

\section{Health Insurance as a Co-Conspirator}

While the edifice of health insurance coverage is crumbling for patients, insurance and managed care leverage, important in holding down hospital costs, also disintegrates when the sellers in a market are consolidating their power. ${ }^{118}$ Consolidation in the industry creates powerful hospitals that "wield considerable market clout when negotiating with health insurers, leading to highly favorable rates that then push up insurance rates."119 Given this saturation, health insurers are unable to effectively hold down costs. ${ }^{120}$ There has been theoretical support for the idea that the way to rein

116 See Adam Sonfield et al., COVID-19 Job Losses Threaten Insurance Coverage and Access to Reproductive Health Care for Millions, HEALTH AFFAIRS, Aug. 3, 2020, available at https://www.healthaffairs.org/do/10.1377/hblog20200728.779022/full/ (last accessed Jan. 28, 2021).

117 See Reed Abelson, Some Workers Face Looming Cutoffs in Health Insurance, N.Y. TIMES, Sept. 28, 2020, available at https://www.nytimes.com/2020/09/28/health/covid-19-health-

insurance.html (last accessed Dec. 22, 2020) ("Tens of millions of people could lose their job-based insurance by the end of the year [2020], said Stan Dorn, the director of the National Center for Coverage Innovation at Families USA, the Washington, D.C., consumer group.”).

118 See Eduardo Porter, Health Care's Overlooked Cost Factor, N.Y. Times, Jun. 11, 2013, available at https://www.nytimes.com/2013/06/12/business/examinations-of-healthcosts-overlook-mergers.html (last accessed Dec. 15, 2020) (noting that hospital mergers are way to secure bargaining leverage with managed care organizations and insurance companies).

119 John Aloysius Cogan Jr., Health Insurance Rate Review, 88 TEMPLE L. REV 411, 427 (2016) ("hospitals and physicians can command greater prices from health insurers since those providers can threaten to walk away from an insurer's network, which could cause significant harm to the profitability of the health insurer").

120 See, e.g., Leslie Stahl, How a Hospital System Grew to Gain Market Power and Drove Up California Health Care Costs, CBS News, 60 MinUTES, Dec. 13, 2020, available at https://www.cbsnews.com/news/california-sutter-health-hospital-chainhigh-prices-lawsuit-60-minutes-2020-12-13/ (last accessed Dec. 15, 2020) (quoting a member of the San Francisco city and county board of supervisors as saying, "Blue Shield is as at the whim of Sutter naming its price as we are. For once in their life the insurance company is not the worst actor in the room, it's Sutter."). 
To be published in 73 HASTINGS L.J. _ (forthcoming 2021-22).

in hospital prices is to allow insurance companies to acquire more market power. ${ }^{121}$

Nonetheless, supercharging insurer market power may not be the answer. Instead, markets that feature dominant hospital systems and dominant health insurers "may experience increases in both hospital prices and insurance premiums," with the dominant companies "agree[ing] to limit competition to benefit both parties, with predictable harms to patient-consumers."122 In this way, large insurance companies and dominant hospital systems can agree to avoid inflicting damage against one another, with the consumer paying in the end.

Further, recent regulatory changes have likely made health insurance less effective as a cost control. Specifically, Affordable Care Act (ACA) regulations may blunt insurance companies' natural incentive to hold down health care costs. ${ }^{123}$ This includes the so-called Medical Loss Ratio (MLR), which requires health insurers to pay no less than either 80 or 85 percent on health care or quality improvement. 124 Under the MLR ratio, insurance companies looking to grow gross profits are incentivized to allow price increases to take hold.125 Indeed, when one's profits are limited by a percentage of the money that it takes in, then increasing the company spend (the size of the pie) is the primary way to increase raw profits. ${ }^{126}$

Within health insurance markets that are noncompetitive-both for (1) ACA individual markets that are

121 See Kirkwood, supra note 22 at 276-78 ("There is little doubt that a merger of substantial insurance companies would result in lower provider prices.").

122 Erin C. Fuse Brown, Irrational Hospital Pricing, 14 Hous. J. HEALTH L. \& POL'Y 11, 30 (2014).

123 See Isaac D. Buck, Affording Obamacare, 71 Hastings L.J. 261, 287 (2020).

124 Julie Appleby, Final Medical Loss Ratio Rule Rebuffs Insurance Agents, KAISER HeALTH News (Dec. 2, 2011), https://khn.org/news/finalmedical-loss-ratio-rule-rebuffs-insurance-agents/.

125 See Buck, supra note 104 at 290.

126 See Marshall Allen, Why Your Health Insurer Doesn't Care About

Your Big Bills, NPR, May 25, 2018, available at https://www.npr.org/sections/health-shots/2018/05/25/613685732/whyyour-health-insurer-doesnt-care-about-your-big-bills (last accessed Dec. 20, 2020) ("It's as if a mom told her son he could have 3 percent of a bowl of ice cream. A clever child would say, 'Make it a bigger bowl.”'). 
To be published in 73 Hastings L.J. _ (forthcoming 2021-22).

feature few competitors, ${ }^{127}$ and (2) employer-based insurance that does not provide employees with much choice of what type of insurance plan they ultimately select ${ }^{128}$ - powerful incentives that improve customer choice do not exist. Without the potent power of the market to push insurance companies to compete on rates, in an uncompetitive market, those companies have less of an incentive to hold down costs. Blunting the insurance companies' typical interests to hold down the cost of premiums could have an impact on their incentives to hold down the inputs in the costs of care. Stories abound of insurance companies that seem to be confusingly content with high health care costs. ${ }^{129}$

\section{E. Retrospective Denial}

Further, insurers' uses of tricky techniques have resulted in ballooning out-of-pocket spending by patients. ${ }^{130}$ In late 2020, Congress was poised to end the practice known as surprise billing, in which an episode of care surprisingly involves an out-of-network provider, causing a much higher

127 See Plan Year 2021 Qualified Health Plan Choice and Premiums in HealthCare.gov States, CENTERs FOR MEDICARE AND MEDICAID SERVICES, Nov. 23, 2020, at 4, available at https://www.cms.gov/CCIIO/Resources/Data-

Resources/Downloads/2021QHPPremiumsChoiceReport.pdf (last accessed Dec. 15, 2020)

128 See Caitlin Owens, Employers, Not Patients, Have the Most Health

Insurance Choices, Axios, Jan. 21, 2020, available at https://www.axios.com/employers-patients-private-health-insurance63c2f9cf-a537-4bf7-af34-5dc040d07eb5.html (last accessed Dec. 15, 2020).

129 See Marshall Allen, Why Your Health Insurer Doesn't Care About Your Big Bills, NPR, May 25, 2018, available at https://www.npr.org/sections/health-shots/2018/05/25/613685732/whyyour-health-insurer-doesnt-care-about-your-big-bills (last accessed Dec. 20, 2020):

Widely perceived as fierce guardians of health care dollars, insurers, in many cases, aren't. In fact, they often agree to pay high prices, then, one way or another, pass those high prices on to patients-all while raking in healthy profits.

130 See, e.g., Sarah Kliff, Coronavirus Tests Are Supposed to Be Free. The Surprise Bills Come Anyway., N.Y. Times, Sept. 9, 2020, available at https://www.nytimes.com/2020/09/09/upshot/coronavirus-surprise-testfees.html (last accessed Dec. 11, 2020. 
To be published in 73 HASTINGS L.J. _ (forthcoming 2021-22).

out-of-pocket bill for the patient following care. ${ }^{131}$ It remains to be seen whether Congress' intervention to address surprise billing amounts to an enduring solution. ${ }^{132}$ Regardless, other tricky techniques for those responsible for financing health care remain.

Retrospective denials occur when the health insurance company, following the administration of treatment, determines that the care was outside of the health insurance contract's coverage scope. ${ }^{133}$ These often follow a prior authorization, when an insurer gives preapproval, or certifies coverage, for a certain procedure or product. ${ }^{134}$ Because prior authorizations can be time-limited, and because the prior authorization itself is not a promise to pay for a procedure, the health insurance company can "change their minds after the fact-citing treatments as medically unnecessary upon further review, blaming how billing departments charged for the work or claiming the procedure was performed too long after approval was granted."135

Retrospective denials can also occur following care that did not require a prior authorization in the first place, with an insurer-after the care is provided-saying that it needed one after all. ${ }^{136}$ Similarly, these denials can also occur where the insurance company-after care is received-determines that the procedure or product in question was not medically

131 See Sarah Kliff and Margot Sanger-Katz, Surprise Medical Bills Cost Americans Millions. Congress Is Finally Set to Ban Most of Them.,

N.Y TIMES, Dec. 20, 2020, available at https://www.nytimes.com/2020/12/20/upshot/surprise-medical-billscongress-ban.html (last accessed Dec. 20, 2020).

132 See Susannah Luthi and Rachel Roubein, How Powerful Health Providers Tamed a "Surprise" Billing Threat, Politico, Dec. 21, 2020, available at https://www.politico.com/news/2020/12/21/surprise-billinghealth-providers-congress-449759 (last accessed Jan. 28, 2021).

133 See John Jacobi et al., Health Insurer Market Behavior After the Affordable Care Act: Assessing the Need for Monitoring, Targeted Enforcement, and Regulatory Reform, 120 PENN ST. L. REV. 109, 130 (2015).

134 See Lauren Weber, Health Insurers Can Use This Loophole to Push Pricy Medical Bills Onto You, the Patient, USA TodAY, Feb. 6, 2020, available

https://www.usatoday.com/story/news/health/2020/02/06/retrospectivedenial-how-health-insurance-practice-works/4671935002/ (last accessed Dec. 21, 2020).

135 Id. 
To be published in 73 HASTINGS L.J. _ (forthcoming 2021-22).

necessary. ${ }^{137}$ These policies have been deployed following emergency department care, drawing the ire of emergency room physicians, who argue that the policies will ultimately encourage patients to delay needed care. ${ }^{138}$ Perhaps more odiously, however, is that these policies are not made aware to patients before they consent to care in the first place, leaving them stuck with a bill for an allegedly non-medically necessary medical intervention, and no way to pay for it.

\section{Litigation As StRATEGY}

After arriving by ambulance at the emergency department, Susan Bradshaw lay on a gurney in her hospital gown with a surgical bonnet on her head, waiting to be wheeled into surgery to remove her appendix at a hospital near her home in Maitland, Fla. A woman in street clothes approached her. Identifying herself as the surgeon's office manager, she demanded that Bradshaw make her $\$ 1,400$ insurance payment before the surgery could proceed.

"I said, 'You have got to be kidding. I don't even have a comb," Bradshaw, a 68-year-old exhibit designer, told the woman on that night eight years ago. "I don't have a credit card on me."

The woman crossed her arms and Bradshaw remembers her saying, "You have to figure it out."139

137 Id. ("After the tests were performed, though, UnitedHealthcare told Pasagic it had deemed the tests medically unnecessary and would not pay for them.").

138 See Eli Richman, Anthem's "Retrospective Denial" Policy for Emergency Care Puts Patients At Risk: Study, Fierce HealthCare, Oct. 22, 2018, available at https://www.fiercehealthcare.com/payer/anthem-sretrospective-denial-policy-at-ers-puts-patients-at-risk-study (last accessed Dec. 22, 2020).

139 Michelle Andrews, Doctors and Hospitals Tell Patients: Show Us the Money Before Treatment, NPR, Dec. 7, 2016, available at https://www.npr.org/sections/health-shots/2016/12/07/504589131/doctorsand-hospitals-tell-patients-show-us-the-money-before-treatment (last accessed Dec. 13, 2020). 
To be published in 73 Hastings L.J. _ (forthcoming 2021-22).

\section{A. Before the Suit}

Even though the courtroom is the setting of the most dramatic example of the hospital's effort to ensure collection on a hospital bill directly from an often-unlawyered patient, ${ }^{140}$ hospitals engage in less draconian efforts to protect their bottom lines. These efforts can begin before the patient leaves the hospital, ${ }^{141}$ or even before its physicians have administered care to the patient. ${ }^{142}$ It has become a strategic process with consequence, as hospitals have spent time on streamlining collections and focus on collecting money from the patient early on in the episode of care. In this vein, hospitals have engaged with patients, educating them about their responsibility to pay ${ }^{143}$ or have assertedly sought to set up a payment arrangement. ${ }^{144}$ Gone are the days when the hospital simply asks patients for money, replaced instead with a strategic plan that aggressively focuses on how to collect. ${ }^{145}$

140 See Bram Sable-Smith, A Wisconsin Hospital Promised to Stop Suing Most Patients During the Pandemic. Then It Filed 200 Lawsuits., Wisconsin PUBLIC RADIO, Dec. 21, 2020, available at https://www.wpr.org/wisconsin-hospital-promised-stop-suing-most-

patients-during-pandemic-then-it-filed-200-lawsuits (last accessed Jan. 12, 2021) ("Gummow navigated the lawsuit without a lawyer, believing she could not afford one. Most debt defendants lack legal representation and don't appear in court," resulting in a default judgment for the hospital).

141 See Harris Meyer, Hospitals Get More Proactive About Bill Collection As Patients' Ability to Pay Deteriorates, Modern HealthCARe, Jun. 28, 2016, available at https://www.modernhealthcare.com/article/20160628/NEWS/160629910/ hos...active-about-bill-collection-as-patients-ability-to-pay-deteriorates (last accessed Dec. 14, 2020).

142 See Susan Morse, Hospitals Increasingly Using Credit Checks to Understand Whether Patients Will Pay, Healthcare Finance News, Mar. 16, 2016, available at https://www.healthcarefinancenews.com/news/hospitals-increasing-

using-credit-checks-understand-whether-patients-will-pay (last accessed Dec. 14, 2020).

143 Roundtable Discussion, Improving the Patient Payment Experience, HealthCare Financial Management Vol. 69, Iss. 5, May 2015.

144 See Meyer, supra note 141. See id. ("a growing number of hospitals are working aggressively with patients before procedures or before they leave the hospital to work out payment").

145 See Jane A. Berkebile, Creating a Positive Culture for Collections, 67 HealthCare Financial Management 100 (Sept. 2013) available at https://pubmed.ncbi.nlm.nih.gov/24050060/ (last accessed Feb. 10, 2021). 
To be published in 73 HASTINGS L.J. _ (forthcoming 2021-22).

One important consideration that hospitals have observed is that "patients are more likely to pay before or during a hospital visit rather than after."146 "Pay and chase" seems increasingly ineffective. ${ }^{147}$ Hospitals now can "run the patient's credit card" and "set up payment plans at the bedside."148

"Imagine," says one hospital revenue director, "if patients could pay their healthcare bills like they pay their hotel bills.... Once the care episode concludes and the insurance claim is adjudicated, the hospital would charge the patient's credit card for the remaining balance and e-mail a receipt."149 One wonders which patients, exactly, would be clamoring for such a system. Another hospital executive has noted that if patients feel as though a hospital payment system "is straightforward and easy," then it "can give the provider an advantage over the competition."150 As if patients choose hospitals for their ease of billing practices.

Unsurprisingly, hospitals have gotten increasingly creative in their efforts. A hospital in Virginia mails bills "under the name of its own collections arm ... which exists only on letterhead," based on a belief that patients are most likely to pay bills that "stand out from hospital bills." 151 Analysts have also encouraged that hospitals adopt a socalled "propensity payment model, which calculates the odds

146 Evans, supra note 108.

147 See Julie Spitzer, A New Patient Engagement Model for Payment Collection, BEckeR's Hospital REview, Oct. 25, 2017, available at https://www.beckershospitalreview.com/finance/a-new-patientengagement-model-for-payment-collection.html (last accessed Dec. 14, 2020) (noting that "providers have to figure out how to get medical bills to be a priority for consumers, and then, they must figure out how to create a sustainable collection model").

148 Improving the Patient Payment Experience, supra note 143.

149 Id

$150 \quad I d$.

Patient balances stand to grow in the future, and hospitals will be continuing their efforts to capture money efficiently and effectively. Payment plans are also probably going to get bigger and more creative. I can even see payment processes becoming similar to those in other service industries.

Id.

151 See Evans, supra note 108. 
To be published in 73 HASTINGS L.J. _ (forthcoming 2021-22).

a patient will pay," based on "balance due, past behavior, and demographics." 152 This can assist the hospital in figuring out where to direct its focus when collecting.

Hospitals have also used credit checks to identify the likelihood that a patient is able to pay for a hospital bill. ${ }^{153}$ In-depth and seemingly intrusive checks, including "lifestyle choices, such as frequent pizza purchases, cigarette buying habits, a fall-off in buying prescription drug refills or a lack of vehicle registration" can also be utilized. ${ }^{154}$ Hospital vendors reportedly look into patients' social media presences, health choices, and purchase histories. ${ }^{155}$ These efforts can identify who needs access to hospitals' financial assistance programs. ${ }^{156}$ They can also identify who is an insured patient with the ability to pay. ${ }^{157}$

Some big players in the hospital industry have even gotten involved in the lucrative business of debt collection. ${ }^{158}$ Subsidiaries of large for-profit hospital chains like HCA and Tenet Healthcare operate profitably within the debt collection world.159 Still other hospitals sell their debt to buyers, perhaps because they "don't want their good names associated with aggressive debt-collection tactics."160

$152 \quad$ See Spitzer, supra note 97.

153 See Morse, supra note 94.

$154 \quad I d$.

155 Id

156 See Beth Kutscher, Patient-Friendlier Financing? Hospitals and Vendors Tout New No-Interest Payment Plans, Modern HealthCARE, Jun. 2, 2014. See also M. Evans, Cash Is King: More Hospitals and Systems Are Using Credit Scores and Financial Records in Collection Strategies-And They're Asking Patients to Pay Upfront., MoDERN HEALTHCARE, Aug. 17, 2009 ("Credit scores also allow hospitals to triage unpaid bills and focus collection efforts on those most likely to pay when reminded.").

157 See Evans, supra note 108 ("It is insured patients with available resources who Fleischer says she hopes to target with earlier credit screening... "Without a down payment, 'you're choosing not to have your healthcare today because you're choosing not to pay your financial obligation,' Fleischer says.”).

158 See John Tozzi, A Hospital Giant Discovers that Collecting Debt Pays Better Than Curing Ills, BloomBerg, Dec. 18, 2017, available at https://www.bloomberg.com/news/features/2017-12-18/a-hospital-giant-

discovers-that-collecting-debt-pays-better-than-curing-ills (last accessed Dec. 22, 2020).

159 Id.

160 See Olga Khazan, What Happens When You Don't Pay a Hospital Bill, THE ATLANTIC, Aug. 28, 2019, available at https://www.theatlantic.com/health/archive/2019/08/medical-bill-debt- 
To be published in 73 HASTINGS L.J. _ (forthcoming 2021-22).

When hospitals demand up-front payment, patients can be left scrambling. This can push patients into entering into monthly payment plans or theorizing, for instance, that they'll use recently disbursed graduate student loans or a friend's credit card for a hysterectomy or appendix removal, respectively, 161 to satisfy the hospital's ask. According to a recent survey, one in eight Americans had to borrow money to afford health care, amounting to $\$ 88$ billion in borrowed funds. ${ }^{162}$ And as of 2017, 43 million Americans owed $\$ 75$ billion in past-due medical debt. ${ }^{163}$ It is no wonder that 45 percent of Americans worry that they could be bankrupted by a medical emergency. ${ }^{164}$

Nonetheless, seemingly marrying this inability to pay with the hospitals desire to collect quickly, a particularly attractive option for hospitals seems to be encouraging patients to open credit cards to pay for medical care, enticed by a zero percent interest rate, ${ }^{165}$ or other payment plans featuring loans. 166 These may allow the hospital to either get

collection/596914/ (last accessed Dec. 21, 2020) (documenting the lengths debt collection agencies undertaken to collect on medical debt, including resorting to LinkedIn requests).

161 See Andrews, supra note 139.

162 See Tami Luhby, Americans Borrow $\$ 88$ Billion Annually to Pay for Health Care, Survey Finds, CNN, Apr. 2, 2019, available at https://www.cnn.com/2019/04/02/health/health-care-costs-

borrowing/index.html (last accessed Dec. 20, 2020).

163 See Tozzi, supra note 137.

164 See The U.S. Healthcare Cost Crisis, Gallup, 2019, available at https://news.gallup.com/poll/248081/westhealth-gallup-us-healthcare-

cost-crisis.aspx (last accessed Dec. 20, 2020).

165 See Beth Kutscher, Patient-Friendlier Financing? Hospitals and Vendors Tout New No-Interest Payment Plans, Modern HealthCARE, Jun. 2, 2014.

166 See Jeff Lagasse, Healthcare Turns to Zero-Interest Loans to Give Patients a Better Reason to Pay, Healthcare Finance News, May 3, 2017, available at https://www.healthcarefinancenews.com/news/healthcare-turns-zerointerest-loans-give-patients-better-reason-pay (last accessed Dec. 20, 2020). 
To be published in 73 Hastings L.J. _ (forthcoming 2021-22).

paid immediately ${ }^{167}$ or to receive a down payment. ${ }^{168}$ Adopting these payment plans has led to greater collections by hospitals. 169 But patients need to be very careful; missing payments can damage one's credit score. ${ }^{170}$

A common credit card option for patients, CareCredit, ${ }^{171}$ says it is accepted by more than 225,000 providers across the United States. ${ }^{172}$ Its website notes that the card can be used at hospital and surgical centers and for labs, imaging and radiology, pharmacy, and specialty care. ${ }^{173}$ According to the company website, the cards offer no interest financing for short term payoffs (up to 24 months) "when [the patient] make[s] the minimum monthly payments and pay[s] the full amount due by the end of the promotional period." 174

Longer-term financing, ranging in length from 24- to 60-month periods, respectively, offer interest rates between 14.9 percent and 17.9 percent. ${ }^{175}$ Failure to pay off the full amount by the end of the promotional period results in the addition of deferred interest (with a reported interest rate of

167 See Health Care Credit Cards, Office of the Minnesota ATTORNEY GENERAL, available at https://www.ag.state.mn.us/consumer/publications/healthcarecreditcards .asp (last accessed Dec. 14, 2020) ("When a patient charges services on a health care credit card, the clinic is paid right away by the credit card company, even if the services are to be delivered in the future."); Ellen Cannon, Medical Credit Cards Are Costly If You're Not Careful, NERDWALLET, Apr. 12, 2017, available at https://www.nerdwallet.com/article/credit-cards/medical-credit-card (last accessed Dec. 14, 2020).

168 See Lagasse, supra note 143.

$169 \quad I d$.

170 See Jo Ling Kent and Michael Cappetta, Some Hospitals Will Now Offer You An Interest-Free Loan, NBC NEWs, May 25, 2017, available at https://www.nbcnews.com/business/business-news/some-hospitals-willnow-offer-you-interest-free-loan-n764236 (last accessed Dec. 20, 2020) ("If patients take out a loan from the hospital, reading the fine print is essential-failing to make payments could result in fines and penalties, as well as damage to credit scores.").

171 See Evans, supra note 107. According to its website, CareCredit has over 11 million customers. See About CareCredit, https://www.carecredit.com/about/ (last accessed Dec. 15, 2020).

172 What Makes CareCredit Different, CARECREDIT, https://www.carecredit.com/howcarecreditworks/prospective/ (last accessed Dec. 14, 2020).

173 See Using CareCredit at Hospitals and Surgical Centers, CARECREDIT, available at https://www.carecredit.com/surgery-centers/ (last accessed Dec. 14, 2020).

174 See What Makes CareCredit Different, supra note 172.

175 Id. 
To be published in 73 HASTINGS L.J. _ (forthcoming 2021-22).

26.99 percent) to the amount owed. ${ }^{176}$ Failure to maintain payments or to satisfy the debt negatively affects the borrower's credit score. ${ }^{177}$

According to CareCredit, customers are "using their card for copayments, deductibles, and prescriptions as out-ofpocket costs continue to rise." 178 While this financing plan may work for some patients, the patient is financing the cost of her care and will likely be responsible for interest if unable to pay off the full balance. This creates the situation in which, because the patient is unable to pay for the deductible, for instance, she seeks to spread out the bill over time to better be able to satisfy it. This financing lifeline can quickly become a high-wire act.

\section{B. From Patient to Defendant}

Even though the number of hospitals pursing aggressive litigation techniques are small in number ${ }^{179}$ and hospitals have reportedly wound down their litigious behavior, ${ }^{180}$ reports suggest that some have continued to sue to collect for unpaid medical bills, even during the pandemic. ${ }^{181}$ These stories are as shocking as they are harrowing. 182

176 See Morse, supra note 97.

177 See Casey Bond and Chris Kissell, Medical Credit Cards: Should You Apply?, U.S News AND WorLD ReporT, Feb. 20, 2020, available at https://creditcards.usnews.com/articles/what-is-a-medical-credit-card (last accessed Dec. 14, 2020).

178 See About CareCredit, supra note 171.

179 See Tara Bannow, Few Hospitals Aggressively Sue Patients to Pay Bills, MODERN HEAlTHCARE, Oct. 5, 2019, available at https://www.modernhealthcare.com/revenue-cycle/few-hospitalsaggressively-sue-patients-pay-bills (last accessed Feb. 9, 2021).

180

181. See Caitlin Owens, Hospitals Still Suing Patients in Coronavirus Hotspots, Axios, Aug. 21, 2020, available at https://www.axios.com/hospitals-lawsuits-patients-coronavirus-7133bf3e4fab-4880-93ff-246ec0c4b0fc.html (last accessed Feb. 12, 2021).

182 See, e.g., Hancock and Lucas, supra note 6 (noting that the University of Virginia Health System sued patients more than 36,000 times from 2012 to 2018 for a total of $\$ 106$ million); Sarah Kliff, With Medical Bills Skyrocketing, More Hospitals Are Suing for Payment, N.Y. TIMES, Dec. 2, 2019, available at https://www.nytimes.com/2019/11/08/us/hospitals-lawsuits-medical- 
To be published in 73 Hastings L.J. _ (forthcoming 2021-22).

Northwell Health, which reversed its legal strategy in January 2021, specifically that "it would stop suing patients during the pandemic and would rescind all legal claims it filed in 2020," had sued 14,000 patients from 2015 to 2019. ${ }^{183}$ According to reporting, for its part, Ballad Health has sued more than 44,000 lawsuits against patients since 2009. ${ }^{184}$

These reports of lawsuits include a number of conscience-shocking stories, from a health system that has placed a lien on a home to secure payment for $\$ 164,000$ following an emergency surgery, ${ }^{185}$ to one that has sued a mom of four children for the $\$ 2,498$ that she owed following a teenager's back surgery, 186 to another that has seized about 25 percent of its former patient's paycheck, making her unable to pay rent following treatment she received following a fall, a car accident, and other maladies. ${ }^{187}$ Further, an undergraduate student had his student registration blocked because he was unable to pay for care he received at the university health center. 188 Another has attracted attention for its new policy that it would end litigation against even its own employees for their medical bills that it is owed. 189

The claims against defendants give the hospital an entry point into the judicially-enforced debt collection process. 190 Indeed, given that "patients typically don't show up to their court date," default judgments against the defendant allow the hospital "to start garnishing their

debt.html (last accessed Dec. 20, 2020) (noting that Ballad hospital system filed "at least 44,000 lawsuits from 2009 to 2019).

183 See Kliff, id. (Northwell was found to have "sued patients far more often than any other hospital chain.”).

184 See id.

185 Hancock and Lucas, supra note 6.

186 See Kliff, supra note 182.

187 See Alex MacGillis, One Thing the Pandemic Hasn't Stopped: Aggressive Medical-Debt Collection, ProPublicA, Apr. 28, 2020.

188 See Hancock and Lucas, supra note 6.

189 See Wendi C. Thomas and Deborah Douglas, "Humbled": Nonprofit Christian Hospital Dials Back Aggressive Debt Collection and Raises Wages After Our Investigation, ProPuBLICA, Jul. 30, 2019, available at https://www.propublica.org/article/methodist-le-bonheurhealthcare-debt-collection-raised-wages-policy-change-after-mlk50-

propublica-investigation (last accessed Feb. 10, 2021).

190 See Michael Barbaro, et al., Why So Many Hospitals Are Suing Their Patients, N.Y TImes, The Daily PodCAst, Dec. 2, 2019, available at https://www.nytimes.com/2019/12/02/podcasts/the-

daily/medicare.html?showTranscript=1 (last accessed Feb. 11, 2021). 
To be published in 73 HASTINGS L.J. _ (forthcoming 2021-22).

patients' wages," and can apply liens to personal property. ${ }^{191}$ According to a study in JAMA, 36 percent of Virginia hospitals sued their patients or garnished their wages in 2017.192 Of the hospitals that sued or garnished, 71 percent were non-profit hospitals. ${ }^{193}$

That hospitals are suing patients for uncollected bills can be warily treated as just another step in, or yet another example of, the failure of the for-profit American health care system. For their part, hospitals can argue that they need to collect on bills to sustain their business models, and for some, particularly those in dire financial straits given their states' inability to expand the Medicaid program under the Affordable Care Act (ACA) ${ }^{194}$ and the current public health crisis, 195 the fact that they have to turn to litigation, against their own patients, is demonstrable of a broken public financial system. In other words, hospitals may argue that it's not their fault. 196

When asked why they sue patients, hospitals seem to raise two arguments: first, the lawsuits are necessary to prevent patients from skipping out of bills that they've fairly incurred, ${ }^{197}$ and second, that the lawsuits are of the patient's making because of some failure to avail themselves of the financial assistance that all hospitals provide. These both

191 Id.

192 See William E. Bruh et al., Prevalence and Characteristics of Virginia Hospitals Suing Patients and Garnishing Wages for Unpaid Medicaid Bills, 322 J. AMER. MED. Ass'N. 691 (2019).

193 Id.

194 See Ge Bai and Gerard F. Anderson, COVID-10 and the Financial Viability of US Rural Hospitals, HEALTH AFFAIRS, Jul. 1, 2020, available at https://www.healthaffairs.org/do/10.1377/hblog20200630.208205/full/ (last accessed Feb. 4, 2021).

195 See Lauren Coleman-Lochner, John Tozzi, and Jeremy Hill, Virus Pushes America's Hospitals to the Brink of Financial Ruin, BLOOMBERG, May 8, 2020, available at https://www.bloomberg.com/news/articles/202005-08/virus-pushes-america-s-hospitals-to-the-brink-of-financial-ruin (last accessed Feb. 2, 2021) (noting that hospitals were expected to post losses of more than $\$ 200$ billion by the end of June 2020).

196 See Brian M. Rosenthal, One Hospital System Sued 2,500 Patients After Pandemic Hit, N.Y. Times, Jan. 5, 2021, available at https://www.nytimes.com/2021/01/05/nyregion/coronavirus-medical-debthospitals.html (last accessed Feb. 2, 2021).

197 See Blake Farmer, It's Not Just Hospitals That Sue Patients Who

Can't Pay, KaIser Health News, Feb. 21, 2020, available at https://khn.org/news/its-not-just-hospitals-that-sue-patients-who-cantpay/ (last accessed Feb. 2, 2021). 
To be published in 73 HASTINGS L.J. _ (forthcoming 2021-22).

give the impression that the hospital really has no choice but to sue their patients.

Northwell Health, a focus of reporting by THE NEW YORK TIMES for its thousands of lawsuits against patients, even after the arrival of COVID-19, has made this argument. ${ }^{198}$ Northwell's chief business strategy officer was reported to have defended the lawsuits, arguing that the health system was owed the bills, and had a right to collect. ${ }^{199}$ "We have no interest in pursuing these cases legally," he said, going on to say that "[i]t's not what we want to do."200 And "[u]nfortunately, in some cases, they're not leaving us much of an option." 201 One may assume he's intimating that patients are not giving the hospital system any choice but to sue them, because they aren't paying for their care.

A similar statement has been shared by Community Health Systems, noting that "[s]ometimes legal action is the only path through which patients will engage in a conversation about the amount they owe for healthcare services that have already been provided."202 Methodist Le Bonheur, which sued more than 8,000 patients from 2014 to 2018 , has stated that "[o]utstanding patient debts are only sent to collections and then to court as a very last resort, and only after continued efforts to work with the patients have been exhausted." 203

Ballad Health is another hospital network that has pursued a strategy of suing its patients. ${ }^{204}$ Tracking Northwell, its vice president for system innovation has been quoted as saying that Ballad is "only pursuing patients who have the means to pay but choose not to pay." 205 Similarly, Carlsbad Medical Center has also been highlighted as a 198 Rosenthal, supra note 196.
199 Id.
200 Id.
201 Id.
202 See Caitlin Owens, Hospitals Still Suing Patients in Coronavirus
Hotspots, AxIOS, Aug. 21, 2020, available at https://www.axios.com/hospitals-lawsuits-patients-coronavirus-7133bf3e4fab-4880-93ff-246ec0c4b0fc.html (last accessed Feb. 12, 2021).

203 See Wendi C. Thomas, The Nonprofit Hospital That Makes Millions, Owns a Collection Agency and Relentlessly Sues the Poor, ProPublicA, Jun. 27, 2019, available at https://www.propublica.org/article/methodist-le-bonheur-healthcaresues-poor-medical-debt (last accessed Feb. 11, 2021)

204 Kliff, supra note 182.

205 Id. 
To be published in 73 HASTINGS L.J. _ (forthcoming 2021-22).

hospital that has adopted a similarly aggressive strategy, filing more than 3,000 lawsuits from 2015 to 2019.206 The Carlsbad CEO has stated that

[w]e sue less than one percent of the patients who receive care at our hospital.... Litigation is always the last resort when our hospital attempts to collect what it is owed for the services we provide. Before initiating a collection suit against anyone, we make multiple attempts - usually trying to contact our patients ten to twelve times-to offer manageable payment plans and additional discounts off of already discounted charges. In many cases, patients do not respond to our calls or letters. ${ }^{207}$

Other spokespeople for hospitals have highlighted the fact that financial assistance is available for patients. ${ }^{208}$

Typically, patients receive more than a dozen contacts via mail or phone call along with multiple opportunities to file for medical or financial hardship. At all points in that process, patients are encouraged to speak with financial counselors; their bills will be forgiven if they can show financial hardship or inability to pay. ${ }^{209}$

According to hospitals, patients "have to cooperate," and must "give [them] the information to confirm what they wrote on their application [for financial assistance]."210

206 Laura Beil, As Patients Struggle With Bills, Hospital Sues Thousands, N.Y Times, Dec. 2, 2019, available at https://www.nytimes.com/2019/09/03/health/carlsbad-hospital-lawsuitsmedical-debt.html (last accessed Feb. 12, 2021).

207 See Elizabeth Cohen and John Bonifield, When Some Patients Don't Pay, This Hospital Sues, CNN, Sept. 10, 2019, available at https://www.cnn.com/2019/09/10/health/carlsbad-new-mexico-hospitaleprise/index.html (last accessed Feb. 2, 2021). See also Owens, supra note 202 (presenting the Community Hospital Systems statement that notes "[l]egal action is always the last avenue considered").

208 See MacGillis, supra note 187.

209 Id.

210 See Jenny Gold, Sued Over An \$1,800 Hospital Bill, KaISER Health News, Apr. 27, 2012, available at https://khn.org/news/charitycare-nonprofit-hospitals-patient-debt/ (last accessed Feb. 10, 2021) 
To be published in 73 HASTINGS L.J. _ (forthcoming 2021-22).

The arguments that hospitals' lawsuits and garnishing wages are "a last resort" have been raised for years, as hospital lawsuits continue to garner attention. ${ }^{211}$ Unfortunately, it appears that these lawsuits-in which a publicly-missioned institution seeks to plug a public funding hole by targeting the very people who the benefit of public financing is designed to help-is not cabined to the health care space. Recent reporting has spotlighted public housing associations turning to litigation to recover unpaid rent, ${ }^{212}$

(presenting the story of a patient being threatened with a lawsuit for bills following prenatal visits,

211 See Jenny Gold, Sued Over An \$1,800 Hospital Bill, KaISER HeALth NEWs, Apr. 27, 2012, available at https://khn.org/news/charitycare-nonprofit-hospitals-patient-debt/ (last accessed Feb. 10, 2021) (presenting the story of a patient being threatened with a lawsuit for bills following prenatal visits,

212 As has been reported, and in a hard-to-believe turn, there are of examples of public housing associations turning to litigation-against residents who qualify for public housing - to "bolster rent collection." See Danielle Ohl, et al., She Was Sued Over Rent She Didn't Owe. It Took Seven Court Dates to Prove She Was Right., ProPublicA, Aug. 25, 2020, available at https://www.propublica.org/article/she-was-sued-over-rentshe-didnt-owe-it-took-seven-court-dates-to-prove-she-was-right (last accessed Dec. 22, 2020). According to recent reporting, in Annapolis, Maryland, in 2018, the Housing Authority of the City of Annapolis filed 1,200 lawsuits against public housing residents. Id. It sued 320 residents, "more than one-third of those who live in its units." Id. The court cases did not typically lead to eviction, but were ruinous for residents' credit scores. Id. 
To be published in 73 Hastings L.J. _ (forthcoming 2021-22).

and school districts suing families for unpaid textbook ${ }^{213}$ and school fees. ${ }^{214}$

\section{A Signal OF CATASTROPHIC FAILURE}

Regardless of the success of the credit card and debt collection market, and regardless of the statements of hospital CEOs, that hospitals have moved toward litigation signals a catastrophic failure in the financing of American health care. It demonstrates the misfit, and tragic ultimate consequence, of the consumer-based paradigm in American health care. It also spotlights the failure of law and policy to adeptly and sufficiently intervene to prevent the worst of a fragmented, for-profit system from hurting patients. And, on a fundamental level, it lays bare the absence of any moral tethering from what hospitals do-taking care of the wellbeing of patients-and how they go about getting paid, which turns their missions into adversaries.

For those steeped in consumerist solutions, given the squeeze that many hospitals feel, and because those with

213 Similar reporting has shone a spotlight on Mishawaka, Indiana, and its school district that is suing students' families for unpaid textbook fees. As was reported, the

[s]chool City of Mishawaka filed 202 lawsuits against parents, with 80 more in August. All told, court records show the district has filed 294 cases since late March, which represents about 5 percent of its enrollment of approximately 5,300 students in the 2019-20 school year. $^{213}$

Ellis Simani and Kim Kilbride, The Pandemic Hasn't Stopped This School District from Suing Parents Over Unpaid Textbook Fees, ProPublicA, Dec. 12, 2020, available at https://www.propublica.org/article/thepandemic-hasnt-stopped-this-school-district-from-suing-parents-over-

unpaid-textbook-fees (last accessed Jan. 24, 2021). The chief financial officer of the district has stated that the district says it has "an obligation to the parents who do pay their fees to collect from those who don't but appear to have the means to pay them." Id.

214 A school district filed 200 cases against families in November of 2020 for unpaid fees. Id. As is often the case, a bill for unpaid textbooks, or a $\$ 240$ bill for candy bars as part of a school fundraiser becomes more than $\$ 350$ after the parent misses the court date. Id. Through these efforts, and by suing these families in court, the school district seems to be attempting to make-up for a funding gap. Id. (noting that the chief financial officer of one of the school districts "thinks the state should try to find a way to reimburse districts for textbooks"). 
To be published in 73 HASTINGS L.J. _ (forthcoming 2021-22).

private insurance have historically enjoyed more robust and protective insurance than other patients coming into the hospital, a hospital adopting an aggressive collection strategy may seem to be emblematic of a noncontroversial attempt to fairly secure funds for care that it has provided. If patients have received services, their insurance does not cover those services, and, as a result, the hospital needs compensation, there is a karmic simplicity to the process. The patient received a benefit, and now must pay. This is the crux of the consumer paradigm in American health care. And treating American health care like any other consumer good lands us here.

But from a public health, health policy, and even health care finance perspective, the decision by hospitals to pursue their patients in court is radically counterproductive to the goals and values of community health, health care policy, and health care finance. This is aggravated when the hospital, the central hub of health care delivery for so many, is the source of the patient's pain.

First, hospital lawsuits are harmful to public health: put simply, they harm the health of the patients they are suing and deters patients from seeking necessary care in the future. Second, it illuminates the failures of American health policy_including a misguided belief in health policy that moral hazard leads to overutilization. In fact, in many instances, it implicates complicating realities of the rules that govern consent as well. Next, it highlights a glaring inconsistency within health care finance, principally spotlighting a categorical error between those with publicly financed insurance and those who have private insurance. And finally, these lawsuits damage patient trust, an important element to a sustainable and adequate health care system.

All four of these impacts demand legal evolution and policy-based recalibration, and all are examined immediately below.

\section{A. Harm to Public Health}

When hospitals sue patients, hospitals flip from working to improve patient health to taking actions that could very well directly harm it. Hospitals seem to recognize this, characterizing their efforts to sue patients for unpaid 
To be published in 73 Hastings L.J. _ (forthcoming 2021-22).

balances as a "last resort." 215 In addition to the impact on physical health, the decision to seek legal action against patients has drastic psychic effects on the hospital-patient relationship, transmuting the hospital from a place of refuge committed, above all, to patient wellbeing, to one which more closely resembles an adversary in a common business transaction.

\section{Financial Toxicity}

Even more directly than positioning oneself as adverse to a patient, lawsuits can actually worsen that patient's health prospects; bankruptcy, it turns out, is very bad for one's health. ${ }^{216}$ Financial toxicity - a term coined from within the world of oncology-encourages providers to be cognizant of how the cost of health care, and how, particularly in the context of the cost of prescription drugs, can dramatically impact the overall health of the patient being treated.217 In a similar manner, far too many patients worry that it is the hospital bill-accompanied by the hospital's aggressive collections actions - that will actually make them sick. ${ }^{218} \mathrm{~A}$

215 See Hancock and Lucas, supra note 6 ("Suing patients or using collection agencies are 'a last resort,' [the health system spokesman] added."). See also Shannon Najmabadi, Some Texas Hospitals Continued to Sue Patients for Unpaid Medical Bills During the Coronavirus Pandemic, TEXAS TRIBUnE, May 27, 2020, available at https://www.texastribune.org/2020/05/27/texas-coronavirus-hospitalssue/ (last accessed Jan. 12, 2021).

216 See Fenaba R. Addo, Seeking Relief: Bankruptcy and Health Outcomes of Adult Women, NCBI, 3 SSM PopUlation HEAlTH 326 (Mar. 20, 2017), available at https://www.ncbi.nlm.nih.gov/pmc/articles/PMC5769037/ (last accessed Dec. 23, 2020) (finding "bankruptcy was ... negatively associated with mental health" and "consumer bankruptcy had an independent and significant negative impact on physical health of older women, lowering the level of self-rated health by a quarter on average"). See also Susan Gubar, The Financial Toxicity of Illness, N.Y. TIMES, Feb. 21, 2019, available at https://www.nytimes.com/2019/02/21/well/live/the-financialtoxicity-of-illness.html (last accessed Dec. 23, 2020) (noting that financial toxicity is "the acute, sub-chronic and chronic burdens of insured, underinsured and uninsured people impaired or destroyed by the high costs of care").

217 See id. See also Isaac D. Buck, The Cost of High Prices: Embedding an Ethic of Expense Into the Standard of Care, 58 B.C. L. REV. 101 (2017).

218 See Michelle Singletary, You Get Sick. Then the Hospital Bill Makes You Ill, Wash. Post, Nov. 14, 2019 
To be published in 73 Hastings L.J. _ (forthcoming 2021-22).

lawsuit would seem to directly conflict with the hospital's mission; medical debt-and all of its related impacts-is a steep cost to pay for one's health. ${ }^{219}$

\section{Impact on Social Determinants of Health}

The study of social determinants of health examines societal conditions and factors that influence one's health. ${ }^{220}$ These factors include a broad array of determinative characteristics, including access to clean air, water, healthy food, health care, housing, education, transportation, income, immigration status, employment, medical debt, family deterioration, and exposure to violence. ${ }^{221}$ Although these have been historically treated as ancillary to health care outcomes, and specifically tangential to what to the daily work of the hospital, scholars have recently highlighted their importance in determining one's health status. 222

Patients who are sued by their hospitals are likely to face a number of stressors that can be expected to negatively impact their health. ${ }^{223}$ In studies, debt has been noted to be

219 See Bram Sable-Smith, A Wisconsin Hospital Promised to Stop Suing Most Patients During the Pandemic. Then It Filed 200 Lawsuits, Wisconsin PUBLIC RADIO, Dec. 21, 2020, available at https://www.wpr.org/wisconsin-hospital-promised-stop-suing-mostpatients-during-pandemic-then-it-filed-200-lawsuits (last accessed Jan. 12, 2021) ("It's absurd that we have to go into debt to be healthy.").

220 See Angela P. Harris and Aysha Pamukcu, The Civil Rights of Health: A New Approach to Challenging Structural Inequality, 67 UCLA L. REV. 758, 762 (2020).

221 See Lindsay F. Wiley, Health Law As Social Justice, 24 CornelL J. L. \& PuB. Pol'y 47, 63 (2014); Matthew B. Lawrence, Against the "Safety Net," 72 FLA. L. REV. 49, 58 (2020); Alice Setrini, Treating Poverty: Legal Tools for Health-Harming Needs, 69 DePAUl L. REv. 77, 79 (2020); Kathy L. Cerminara \& Barbara A. Noah, Removing Obstacles to a Peaceful Death, 25 ELDER L.J. 197, 228 (2018).

222 See id.

223 See Hancock and Lucas, supra note 6:

Heather Waldron and John Hawley are losing their fourbedroom house in the hills above Blacksburg, Va. A teenage daughter, one of their five children, sold her clothes for spending money. They worried about paying the electric bill. Financial disaster, they say, contributed to their divorce, finalized in April. Their money problems began when the University of Virginia Health System pursued the couple with a lawsuit and a lien on their home 
To be published in 73 HASTINGS L.J. _ (forthcoming 2021-22).

a particularly prevalent factor that impacts patients and their health. ${ }^{224}$ But when hospitals sue patients, other social determinants-like those patients' access to secure housing, education, and even personal relationships-can be put at risk. ${ }^{225}$

\section{Deterring Future Care}

Beyond the negative impact on one's health, other downstream consequences could follow the decision by the hospital to sue. First, and most simply, seizing one's assets makes an individual less likely to be able to afford necessary medical care in the future. ${ }^{226}$ Hospitals have garnished wages, leaving the patient with meager disposable income, if any. ${ }^{227}$ When the individual has no choice but to seek care from the exact same hospital, beside the shame and embarrassment they feel, ${ }^{228}$ they could find themselves in a debt spiral, leading to an additional medical bankruptcy. ${ }^{229}$

to recoup $\$ 164,000$ in charges for Waldron's emergency surgery in 2017.

224 See Frank Griffin et al., The Law and Social Determinants of Health: A Clinical Study of Orthopedic Outpatients, 15 J. HEalth \& BIOMEDICAL L. 145, 149 (2018) (noting that "debt was the most common issue facing the patients in our study").

225 See Hancock and Lucas, supra note 6.

226 See Bram Sable-Smith, A Wisconsin Hospital Promised to Stop Suing Most Patients During the Pandemic. Then It Filed 200 Lawsuits, WisCONSIN PUBLIC RADIO, Dec. 21, 2020, available at https://www.wpr.org/wisconsin-hospital-promised-stop-suing-most-

patients-during-pandemic-then-it-filed-200-lawsuits (last accessed Jan. 12, 2021) ("It's absurd that we have to go into debt to be healthy. And if we don't have the money, we can't go to the doctor.").

227 See Selena Simmons-Duffin, When Hospitals Sue for Unpaid Bills, It Can Be "Ruinous" For Patients, NPR, June 25, 2019, available at https://www.npr.org/sections/healthshots/2019/06/25/735385283/hospitals-earn-little-from-suing-for-unpaidbills-for-patients-it-can-be-ruinous (last accessed Dec. 11, 2020).

228 See Michael Barbaro, et al., Why So Many Hospitals Are Suing Their Patients, N.Y TIMEs, THE DAILY PoDCAST, Dec. 2, 2019, available at https://www.nytimes.com/2019/12/02/podcasts/the-

daily/medicare.html?showTranscript=1 (last accessed Jan. 12, 2021) (noting the patient's discomfort in seeking care at the same hospital that was suing her for non-payment following care her daughter sought).

229 Laura Ungar, Heart Disease Bankrupted Him Once. Now He Faces Another \$10,000 Medical Bill, NPR, Sept. 25, 2020, available at https://www.npr.org/sections/health-shots/2020/09/25/916514499/heartdisease-bankrupted-him-once-now-he-faces-another-10-000-medical-bill 
To be published in 73 HASTINGS L.J. _ (forthcoming 2021-22).

Aside from leaving patients unable to open their wallets in the future, the decision has the mental impact of deterring those patients from seeking necessary care in the future. ${ }^{230}$ Follow-up care, pain treatment, and additional health care concerns go untreated due to a fear of expense. ${ }^{231}$ Patients without a choice, particularly rural individuals who need to seek care, may be forced to visit the very hospital for care that is suing them. ${ }^{232}$

This supercharges the factors that lead to an alarming percentage of all Americans who delay health care due to their inability to pay for it. A 2018 survey suggested that as many as 30 percent of Americans or someone in their household skipped a dental checkup, 26 percent postponed needed care, and 21 percent skipped a recommended medical test or treatment. ${ }^{233}$ More than half of Americans surveyed reported delaying treatment, or settling for some cheaper over-the-counter drug, resulting in 13 percent reporting that their medical conditions worsened as a result. ${ }^{234}$ Made worse by the coronavirus pandemic, Americans with financial stress are delaying necessary health care appointments. ${ }^{235}$

(last accessed Jan. 12, 2021) (quoting 31-year-old Matthew Fentress of Louisville, Kentucky, who faces a second potential medical bankruptcy, following a surgical procedure known as an ablation in an effort to correct a heart arrhythmia).

230 See Kliff, supra note 182:

"It makes you think twice about going to the doctor," she said. "I haven't been feeling well for a couple of months, there's something wrong with my stomach, and everyone is like, 'Go in, go in.' But I just can't. There will be more doctor bills."

231 See Hancock and Lucas, supra note 6 ("UVA, where she got surgery and metal implants, sued her for $\$ 9,505$ and rejected her request for financial help. A UVA representative said she could sell some acreage from her small rural home to pay the bill, she said. She limps and is in pain, but 'I can't afford to go back,' she said.").

232 See Barbaro, et al., supra note 229.

233 See Ashley Kirzinger et al., Data Note: Americans' Challenges with Health Care Costs, KAISER FAMILY Found., Jun. 11, 2019, available at https://www.kff.org/health-costs/issue-brief/data-note-americans-

challenges-health-care-costs/ (last accessed Jan. 11, 2021).

234 Id.

235 See Reed Abelson, Why People Are Still Avoiding the Doctor (It's

Not the Virus), N.Y. Times, Jun. 16, 2020, available at https://www.nytimes.com/2020/06/16/health/coronavirus-insurance-

healthcare.html (last accessed Jan. 12, 2021) (noting that Americans, after the 
To be published in 73 Hastings L.J. _ (forthcoming 2021-22).

\section{B. Harm to Health Policy}

From a simple consumerist perspective-the lens that, without radical reform, continues to be dominant in so many corners of American health care-patients who end up being sued by hospitals that recently treated them must be making poor consumer choices. After all, a private market will not naturally rescue a consumer from their own purchasing mistakes. If an individual buys a new car but refuses to pay her share of what is owed, she is undoubtedly opening herself up to suit, or at least some sort of adversarial interaction from the seller or lender. ${ }^{236}$ Further, if the buyer finds out later that the service for which she contracted was unnecessary or becomes undesirable, she still burdens the loss. It is the consumer-based paradigm that leads to this unsurprising result.

Of course, in health care, if the patient does not pay, we know the analogy cannot be applicable. Indeed, the procedure has already been completed and it is not possible to repossess the surgery that was performed or the drugs that were administered. But the same moral judgment seems to persist: why did the individual seek care if she could not afford it?

The Consumer Paradigm. Perhaps the consumerpatient fully knew and appreciated that she would be stuck with a bill, but proceeded with consenting to care anyway. From a patient knowledge or agency perspective, these are the individuals for which aggressive collection techniques, following a period of attempts by the hospital to collect, if they make sense for anyone, may make most sense. ${ }^{237}$ Of course,

2008 recession, "learned to forgo care rather than incur bills they can't pay").

236 See Stefan Lembo Stolba, How Does Repossession Work?, EXPERIAN, Sept. 6, 2020, available at https://www.experian.com/blogs/askexperian/how-does-repossession-work/ (last accessed Dec. 22, 2020) ("When a vehicle owner is in default and is non-responsive to the lender's attempts to remedy the missed payments, the creditor may choose to repossess the vehicle."); Sebastian Blanco, Auto Repossessions Likely to

Rise in 2021 as COVID-19 Pandemic Goes On, CAR AND DRIVER, Nov. 29, 2020, available at https://www.caranddriver.com/news/a34813379/autorepossessions-predicted-up-2021/ (last accessed Dec. 23, 2020) (predicting a surge in repossessions in 2021 as a result of the COVID-19 crisis).

237 See Anna Werner, Alabama Couple Struggling After Hospital Sues Over Medical Debt: "I Wish You'd Have Let Me Die," CBS News, Feb. 20, 
To be published in 73 HASTINGS L.J. _ (forthcoming 2021-22).

if the individual proceeds with the medically necessary episode of care, but cannot afford the bill that follows, ${ }^{238}$ whether or not that individual should be saddled with the medical bill is still a societal question that should be up for debate. ${ }^{239}$ Given the fact that other swathes of the population do not experience such cost exposure suggests that exposing these individuals to substantial cost sharing seems at least morally dubious.

Emergency Care. The consumer-based analog is completely inapplicable if the care was emergent; the individual did not have a choice in whether she had to access care. This is the case for the scenarios in which the emergency room seeks payment for procedures that were performed out of emergent necessity. In these cases, the consumer paradigm rings completely hollow because the consumer has no ex ante agency at all.

Maybe the consumer-patient is directed by her provider to go to the emergency room during a bout with severe anemia, for example, and simply does not have a choice. ${ }^{240}$ Or maybe the situation involves a single mother

2020, available at https://www.cbsnews.com/news/health-care-costsalabama-hospital-sues-patient-to-collect-medical-debt-afterappendectomy/ (last accessed Dec. 22, 2020):

It is our strong preference to work directly with patients. Unfortunately, some individuals refuse to engage with us to resolve their balances. Litigation is always a last resort and is only pursued after we determine the patient has the financial ability to make some level of payment based on employment status and credit record.

Id.

238 See Bannow, supra note 179 (noting that "the idea that health systems are suing wealthy people who aren't paying for plastic surgery is not true," and citing a study that found "that the most common employers of patients having their wages garnished were Walmart, Wells Fargo, Amazon and Lowe's").

239 See Public Opinion on Single-Payer, National Health Plans, and Expanding Access to Medicare Coverage, KAISER FAMILY FOUNDATION, Oct. 16, 2020, available at https://www.kff.org/slideshow/public-opinionon-single-payer-national-health-plans-and-expanding-access-to-

medicare-coverage/ (last accessed Dec. 22, 2020) (documenting public support of various universal public health care insurance plans).

240 See Blake Farmer, Nashville Emergency Room Sues 800 Patients Over Unpaid Bills, U.S. News AND WoRLD ReporT, Dec. 22, 2019, available at https://www.usnews.com/news/beststates/tennessee/articles/2019-12-22/nashville-emergency-room-sues-700- 
To be published in 73 Hastings L.J. _ (forthcoming 2021-22).

who has taken her child to the emergency room with an asthma attack. ${ }^{241}$ Or, perhaps, the patient (in this instance, uninsured) needed an emergency appendectomy. ${ }^{242}$

In these cases, the typical consumer paradigm - that the patient is able to make a balanced decision about whether to seek care, and whether she can afford it-doesn't work. In a particularly sad result, patients, without means to pay for astronomical bills, lament the fact that the hospital that offered care in the first place saved their life. ${ }^{243}$ "I wish you'd have let me die," scream the headlines. ${ }^{244}$

Nonetheless, examples of this categorical type do represent multiple shades of gray. Some emergent care is truly unconsented-to, but there is other necessary health care that an individual consents to, and may feel (or be told) that that care is necessary. It is hardly the case the individual is making a free choice to consent to these necessary procedures, and it is hardly the case that these procedures are elective. Another way to say it is that it would seem that few come to the hospital for fun, giving credence to the idea that most of these cases are not fully chosen realities, which again highlights the massive limitations of the consumer-based paradigm in American health care.

Incomplete and/or Incorrect Information. The third category encompasses cases of incomplete patient information. These are cases where a patient reasonably, but incorrectly, believes that the care she is receiving from a

patients-over-unpaid-bills (last accessed Dec. 22, 2020) ("He called me back that Halloween day and said, "I need you to get to the emergency (room), stat, and they're waiting on you when you get there," she recalls.").

241 See Laura Beil, As Patients Struggle With Bills, Hospital Sues Thousands, N.Y Times, Dec. 2, 2019, available at https://www.nytimes.com/2019/09/03/health/carlsbad-hospital-lawsuitsmedical-debt.html (last accessed Dec. 22, 2020) ("Ms. Price let the summons go unanswered, figuring she would settle the balance-with interest, about $\$ 3,600-$ when she could. A few months later, she opened her paycheck and discovered the hospital had garnished her wages by $\$ 870$ a month. Her car was soon repossessed because she could no longer make the payments. She was on the verge of losing her house, too, when her mortgage company steppe din to help her save it.").

242 See Werner, supra note 238 (noting the fact that a hospital sued an uninsured patient for nearly $\$ 37,000$ following an emergency appendectomy).

243 Id. 
To be published in 73 Hastings L.J. _ (forthcoming 2021-22).

hospital is fully covered by her insurance, or at least that her cost exposure is limited and satisfiable. ${ }^{245}$

One can easily imagine this scenario: after all, hospital bills are notoriously byzantine and complex. ${ }^{246}$ Examples of this category could include the problem of surprise billing, ${ }^{247}$ which was finally regulated by Congress in late 2020. ${ }^{248}$ Even patients suffering health emergencies with the wherewithal to call ahead to see if their insurance plan covers the type of care they will need have been unable to avail themselves of

245 See Ungar, supra note 1 ("Financial fears reignited this year when his cardiologist suggested that he undergo an ablation procedure to restore a normal heart rhythm. He says hospital officials assured him he wouldn't be on the hook for more than $\$ 7,000$, a huge stretch on his $\$ 30,000$ annual salary.” He then received a bill for $\$ 9,673.71$.).

246 See David Royse, Confusing Hospital Bills Driving Growth in Bad Debt, MODERN HeAlTHCARE, May 13, 2017, available at https://www.modernhealthcare.com/article/20170513/TRANSFORMATI ON02/170509877/confusing-hospital-bills-driving-growth-in-bad-debt (last accessed Dec. 22, 2020) ("David Silverstein's frustrations trying to understand the hospital charges for his daughter's sports injuries drove him to consider going to court. He had the money to pay. He simply refused because he couldn't get a Providence Health \& Services hospital in Spokane, Was., where his daughter was away at college, to explain the prices in her bills.").

247 See Karan Chhabra et al., Out-of-Network Bills for Privately Insured Patients Undergoing Elective Surgery With In-Network Primary Surgeons and Facilities, J. AMERICAN MED. Ass'N., Feb. 11, 2020, available at

https://jamanetwork.com/journals/jama/fullarticle/2760735?guestAccess Key=9774a0bf-c1e7-45a4-b2a0-

32f41c6fde66\&utm_source=For_The_Media\&utm_medium=referral\&ut

m_campaign $=$ ftm_links\&utm_content $=$ tfl\&utm_term $=021120 \quad$ (last accessed Dec. 23, 2020); Elena Renken, Study: 1 in 5 Patients Gets a Surprise Medical Bill After Surgery, NPR, Feb. 11, 2020, available at https://www.npr.org/sections/health-shots/2020/02/11/804906330/study1-in-5-patients-gets-a-surprise-medical-bill-after-surgery (last accessed Dec. 23, 2020) ("Tracking data from almost 350,000 patients with a large commercial insurer, the researchers found that more than 20 percent were hit with an out-of-network charge," and that the "average bill was over $\$ 2,000$ more than what insurance would typically pay").

248 See Sarah Kliff and Margot Sanger-Katz, Surprise Medical Bills Cost Americans Millions. Congress Finally Banned Most of Them., N.Y. TIMES, Dec. 22, 2020, available at https://www.nytimes.com/2020/12/20/upshot/surprise-medical-billscongress-ban.html (last accessed Dec. 23, 2020) (noting the new rules will take place in 2022, and will force health providers and insurers to come up with a fair price to charge). 
To be published in 73 HASTINGS L.J. _ (forthcoming 2021-22).

complete and clear information, and have been stuck with massive bills. ${ }^{249}$

Worse than incomplete information is incorrect information about patients' cost exposure. Stories abound of individuals believing care was covered by an insurance plan, only to find out that it was not. 250 Some patients allege they were assured by the hospital that certain procedures would be covered by their insurance, only to be stuck with a huge out-of-pocket obligation. ${ }^{251}$

Worse still, some patients have been forced into bankruptcy due to tens of thousands of dollars in medical bills after their insurance company authorized the procedure, a practice known as retrospective denial.252 A classic example of retrospective denial involves a story involving 53-year-old Darla Markley, who had suffered from transverse myelitis. ${ }^{253}$ In her case, Markley agreed to undergo expensive tests at the Mayo Clinic following notice from the insurer that the testing was preapproved and covered by her plan. ${ }^{254}$

Following the tests and an additional diagnosis, she was told that the insurance company "judged that the tests weren't needed after all and refused to pay" for the tests that

249 See Lindsey Bomnin and Stephanie Gosk, Surprise Medical Bills Lead to Liens on Homes and Crippling Debt, NBC News, Mar. 19, 2019, available at https://www.nbcnews.com/health/health-news/surprisemedical-bills-lead-liens-homes-crippling-debt-n984371 (last accessed Dec. 23, 2020) ("She rushed to a nearby hospital, Swedish Medical Center-but first called ahead to make sure it took her insurance. When the hospital said yes, Briggs thought that meant she was covered.... But two months after the surgery, she got a whopping bill for $\$ 4,727$ from the surgeon, Dr. Emmett McGuire. Like most of the doctors at the hospital, McGuire practiced independently. He did not take her insurance.").

250 See Hancock and Lucas, supra note 6 ("When Jesse Lynn, 42, of Orange County, bought short-term coverage to tide him over between policies, he and his wife, Renee, didn't realize the plan considered Jesse's old back problems a preexisting illness, and therefore would not pay for treatment. After back surgery at Culpeper Medical Center, a UVA affiliate, he came out with a bill for about $\$ 230,000$, Renee Lynn said.”).

251 See Ungar, supra note 1.

252 See Lauren Weber, Patients Stuck With Bills After Insurers Don't Pay As Promised, Kaiser Health News, Feb. 7, 2020, available at https://khn.org/news/prior-authorization-revoked-patients-stuck-with-

bills-after-insurers-dont-pay-as-promised/ (last accessed Dec. 23, 2020) ("The more than $\$ 34,000$ in medical bills that contributed to Darla and Andy Markley's bankruptcy and loss of their home in Beloit, Wisconsin, grew out of what felt like a broken promise.").

$\begin{array}{ll}253 & I d . \\ 254 & I d .\end{array}$ 
To be published in 73 HASTINGS L.J. _ (forthcoming 2021-22).

they had previously approved. ${ }^{255}$ Although the insurance company denies that they have records that show this sequence of events, Markley says "she never would have had the tests done if she had known insurance was not going to pay for them." 256 Other insurance companies, such as Anthem, have come under scrutiny for their retrospective denial policy, deployed against patients even following emergency room visits. 257

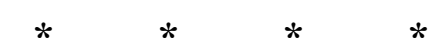

At least for the patients who incur out-of-pocket expenditures as a result of incomplete or incorrect information, or those who are in such an emergent condition that their care naturally follows, the current state of affairsthat a hospital can sue the patient for unpaid medical billsseems to be a major policy failure. Similar to those who are misled into consenting to a contract, or even those who never even consent in the first place, those patients who believe that their health insurance covers the care to which they consent, and whose coverage determination is vital to their decision that ultimately results in their giving that consent-should have some defense to hospitals' lawsuits seeking compensation from their own pockets.

In this way, it appears that some of these agreements resemble a type of conditional agreement. As such, patients could argue that their consent to the proposed procedure is conditional on, or depends upon, their insurance plans' coverage. This argument would protect patients who consent to a procedure under the misguided understanding that their insurance plan will pay for the care that is delivered.

At the very least, there appears to be a strong argument that the necessary meeting of the minds cannot occur where one party is under a radical misimpression about a material element of the proposed contract. Further, contract law scholars may even argue that a contract remedy, based on the fact that treatment agreements are incomplete

$255 \quad I d$

$256 \quad I d$.

257 See Richman, supra note 121 ("Anthem has justified its policy as a way to reduce unnecessary ER visits. By targeting diagnosis codes it determined to be nonemergent, the insurer hoped to divert those ER visits to less-expensive forms of healthcare such as retail clinics."). 
To be published in 73 HASTINGS L.J. _ (forthcoming 2021-22).

contracts, could exist. ${ }^{258}$ Of course, this does not effectively solve the problem of patients who, after realizing that their insurance may not cover the majority of the cost of the proposed procedure, decline to undergo care that is necessary and appropriate.

\section{Harm to Health Finance}

When hospitals sue patients, they expose inequities and inconsistencies within the health care finance superstructure. In addition to raising serious questions about sacredly-health beliefs and interventions within health care economics, hospital lawsuits demonstrate the lack of protections for insured patients who face high out of pocket expenditures. For these individuals, a slightly lower income (Medicaid) or a few more years of age (Medicare) would qualify them for publicly-run insurance and financing programs, sheltering them from some of the hospitals' most aggressive collections practices. Indeed, for those lacking in health insurance, hospital charity care is typically targeted and available, perhaps to the detriment of the hospital's bottom line. ${ }^{259}$ But for those who enjoy employment-based insurance, too many face hospital collection efforts. It is here where law has intervened in the past to protect American patients whose experience with the American health care system is negatively impacted by cost, and whose access to care is threatened by it. ${ }^{260}$

\section{The Death of Moral Hazard}

High-deductible insurance plans that a growing number of Americans depend upon rely on policy tools that

258 See Wendy Epstein, Price Transparency and Incomplete Contracts in Health Care. 67 EMORY L.J. 1 (2017).

259 See Lisa Rapaport, Nonprofit Hospitals With Healthiest Finances Offer Little Charity Care, REUTERS, Feb. 17, 2020, available at https://www.reuters.com/article/us-health-hospitals-charity/nonprofithospitals-with-healthiest-finances-offer-little-charity-careidUSKBN20B1WS (last accessed Jan. 12, 2021).

260 See Emergency Medical Treatment and Active Labor Act, 42 U.S. Code $§ 1395 \mathrm{dd}$ (2020) (requiring the administration of emergency care by the hospital regardless of ability to pay). 
To be published in 73 HASTINGS L.J. _ (forthcoming 2021-22).

discourage overconsumption of health care services. ${ }^{261}$ This is a relatively easy policy goal to grasp: if the health insurance plans force patients to "put skin in the game," or to experience some financial pain for their utilization of health care services, then they will be more aware of the cost of the health care that they incur, and will be willing to consent to such procedures only when absolutely necessary. ${ }^{262}$ This policy solution is based on one of the central beliefs that health care costs are driven by overutilization, and that overutilization is being driven by what is known as moral hazard. ${ }^{263}$ Thus, the thinking goes, insurance that requires more out-of-pocket expenditure by the patient will pressure the patient into consuming less, pushing down the overall health care budget. ${ }^{264}$

But in the cases where hospitals sue their patients, this belief is cast in serious doubt. First, if moral hazard truly were a driver of excess hospital costs, and if the system were calibrated to appropriately prevent those unnecessary expenditures, then few patients would ever be sued. Instead, in those contexts, the concerns raised by moral hazard have limited purchase. As a result, these medical decisions cannot be characterized as typical consumer transactions, and cannot be treated similarly.

Second, and relatedly, the formula-intended to dissuade patients from seeking care that they do not really need-should not apply when the care that is sought seems to be necessary. This problem has been raised before in criticizing the proliferation of high-deductible insurance

261 See Emily Gersema, High Deductible Health Plans Raise Risk of Financial Ruin for Vulnerable Americans, Study Finds, USC News, Apr. 5, 2018, available at https://news.usc.edu/140182/high-deductible-healthplans-raise-risk-of-financial-ruin-for-vulnerable-americans-study-finds/ (last accessed Jan. 27, 2021) ("Advocates of the plans say high deductibles give consumers more skin in the game to become judicious price shoppers for health care services and stash money in their health savings accounts (HAS) for basic care and emergencies.").

$262 I d$.

263 See Peter Molk, The Ownership of Health Insurers, 2016 U. ILL. L. REV. 873, 885 (2016) ("In health insurance, moral hazard is the phenomenon where individuals consume more medical services when they are insured than when they are uninsured, because insurance reduces the policyholder's marginal cost of consuming healthcare.").

264 Id. ("Insurers combat moral hazard through various cost-sharing arrangements that force policyholders to internalize some of their costs of medical care.”). 
To be published in 73 Hastings L.J. _ (forthcoming 2021-22).

plans. ${ }^{265}$ When the system requires substantial levels of cost exposure for patients following necessary treatment, it begins to look like a rougher financing strategy-that the hospital is just going to expect a certain (higher) percentage from its patients to discharge their bills. If the care truly is necessary, then increased cost sharing seems self-destructive. It also gives hospitals the opening to sue those patients to make sure they contribute to their health care expenditures, signaling a financing system - one that should spread risk and loss fairly and adequately - that has seemingly gone completely off the rails.

\section{The Medical Necessity Quirk}

The inequities and inconsistencies in the financing system are brought into stark relief when one watches a lawsuit between a hospital and its former patient unfold. It is made even more noteworthy when one recognizes how many other patients-with different types of health insurance-are shielded from similar financial liability related to their care. This is particularly jarring when one examines the difference between a Medicare beneficiary and a privately-insured beneficiary on this score.

One can observe the policy-based disparities that exist between a Medicare beneficiary and an individual who gets health insurance through their employment. As has been the case over the course of Medicare policy determinations known as national coverage determinations (NCDs), ${ }^{266}$ imagine that a Medicare beneficiary is administered a procedure by a provider that is ultimately deemed to be lacking in medical necessity. If the provider should bill for that procedure-the procedure that lacks medical necessity, according to

\footnotetext{
265 See Darla Mercado, High-Deductible Insurance Deters Doctor Visits, CNBC, Sept. 7, 2016, available at https://www.cnbc.com/2016/09/07/high-deductible-insurance-detersdoctor-visits.html (last accessed Jan. 27, 2021) ("Across the board, workers who enrolled in the high-deductible plan saw the doctor less. This was a problem especially for lower-income employees."). See RoBERTSON, supra note 11.

266 See Medicare Coverage Determination Process, CENTERs FOR MEDICARE AND MEDICAID SERVICES, Dec. 17, 2020, available at https://www.cms.gov/Medicare/Coverage/DeterminationProcess (last accessed Feb. 3, 2021) ("National coverage determinations (NCDs) are made through an evidence-based process, with opportunities for public participation.”).
} 
To be published in 73 HASTINGS L.J. _ (forthcoming 2021-22).

Medicare-then Medicare does not have to pay for that service. ${ }^{267}$

What's more, Medicare could even allege that the administration of that care that is lacking in medical necessity is fraudulent. ${ }^{268}$ After all, the provider is filing a claim for reimbursement with the federal government to pay for a procedure that lacks medical necessity. Medical necessity-based fraud is actionable. ${ }^{269}$

And the federal government, with strong tools like the civil federal False Claims Act (FCA), ${ }^{270}$ can allege that a claim submitted to Medicare for reimbursement for care that lacks medical necessity is a false claim. A fraud investigation could follow. ${ }^{271}$ In short, hospitals who face this potential sharp edge of liability are incentivized to be mindful of their doctors' determinations of medical necessity.

It is a different world when the patient is not a Medicare beneficiary, but instead, has private insurance. Indeed, in the cases mentioned supra, ${ }^{272}$ the end point of the scenario is completely different. Here, where patients

267 Although this sketch could also happen within the Medicaid program, it is more common, and has drawn more attention, within the Medicare program. This could be because of the disparity in reimbursement rates between the programs, among other factors.

268 See Medicare Fraud \& Abuse: Prevent, Detect, Report, CENTERS FOR MEDICARE AND MEDICAID SERVICES, Feb. 2019, available at https://www.cms.gov/Outreach-and-Education/Medicare-Learning-

Network-MLN/MLNProducts/Downloads/Fraud-Abuse-MLN4649244.pdf (last accessed Jan. 27, 2021).

269 See, e.g., Isaac D. Buck, Overtreatment and Informed Consent: A Fraud-Based Solution to Unwanted and Unnecessary Care, 43 FLA. ST. U. L. REV. 907, 948-950 (2016) (identifying fraud based on medical necessity as a discrete type of actionable cases). See also Winter v. Gardens Regional Hospital and Medical Center, 953 F.3d 1108 (9th Cir. 2020) ("We therefore hold that a false certification of medical necessity can give rise to FCA liability. We also hold that a false certification of medical necessity can be material because medical necessity is a statutory prerequisite to Medicare reimbursement."); Isaac D. Buck, A Farewell to Falsity: Shifting Standards in Medicare Fraud Enforcement, 49 SETON HALL L. REV. 1 (2018).

270 See 31 U.S.C. 3729 et seq.

271 See Harris Meyer, Can a Doctor's Medical Necessity Decision Be a False Claim?, MODERn HEAlTHCARE, Feb. 16, 2019, available at https://www.modernhealthcare.com/article/20190216/NEWS/190219948/c an-a-doctor-s-medical-necessity-decision-be-a-false-claim (last accessed Jan. 27, 2021) (noting the intricacies of medical necessity-based fraud investigations and cases).

272 Cases of hospitals suing patients due to retroactive claim denial. 
To be published in 73 HASTINGS L.J. _ (forthcoming 2021-22).

consent to a procedure thinking that the procedure is both medically necessary and covered by their private employerbased insurance, a subsequent determination by the insurance company-which concludes that the care administered by the hospital is not medically necessary after all273 - a scenario results where the patient is on the hook for the bill. As a result, where the hospital is determined to collect the portion of the bill that is not covered by the patient's health insurance, the patient-who may be unable to pay for that difference-is eventually the target of the hospital's litigation strategy. This path eventually leads to the courthouse.

A few observations are important. In the first example - that is, the cases in which the patient is a Medicare beneficiary, administering care to that patient that is-in Medicare's estimation — not medically necessary may subject that hospital to a fraud action. Requiring the Medicare beneficiary, in that instance, to pay the cost of the care provided - and to be prepared to be sued for a failure to cover the cost—seems patently absurd.

The specific difference between the Medicare patient and the private payer patient highlighted throughout demonstrates the decision by policy-makers and the American public that health care provided to Medicare beneficiaries is a public good. Public financing attaches to the Medicare beneficiary, as does robust fraud and abuse enforcement. For the Medicare beneficiary, health care access and delivery is protected, imagining adverse litigation is ludicrous, and, although beneficiaries are often responsible for about 20 percent in co-insurance for Part B, ${ }^{274}$ where the Medicare reimbursement does not cover the full cost of the care (according to the hospital), the hospital covers or eats the difference.

Alternatively, for those with private-paying insurance, those who cannot afford to pay a high deductible and who are sued as a result, are not patients who are part of the public financing system's protective umbrella. This paradigm is so strong that it does not currently kick in to protect patients who are sued by the hospital that once administered care to

273 See notes and discussion, supra nn. 133-38.

274 See Medicare Costs at a Glance, MEDICARE.Gov, https://www.medicare.gov/your-medicare-costs/medicare-costs-at-aglance (last accessed Jan. 24, 2021). 
To be published in 73 Hastings L.J. _ (forthcoming 2021-22).

them. This even holds for patients who are completely unable to afford the hospital bills they receive, and for patients whose insurance plans initially approved the care at issue.

As this starkly indicates, the policy boundary between these patients is not tied to financial need, but rather, insurance type. A Medicare patient who cannot afford the full price of their health care bill is protected, and a patient with private insurance is sued. These type of distinctions are common throughout the American health care enterprise, to be sure. Unsurprisingly, these craggy cliffs of policy-based line drawing can breed resentment between different groups, ${ }^{275}$ and must be addressed.

\section{Harm to Patient Trust}

Finally, these lawsuits have the tendency to damage and destroy patient trust. ${ }^{276}$ Trust is the foundation to the patient-physician relationship. ${ }^{277}$ Without it, patients do not seek care when in need, and don't take physicians' advice when they should. ${ }^{278}$

In addition to exacting devastating consequences on public health writ large, hospital lawsuits seem to vitiate something sacrosanct, and something deeply personal, in the health care system between individual patients and their providers. ${ }^{279}$ As such, it seems likely that hospital lawsuits

275 See Abby Goodnough, As Some Got Free Health Care, Gwen Got Squeezed: An Obamacare Dilemma, N.Y. TIMES, Feb. 19, 2018, available at https://www.nytimes.com/2018/02/19/health/obamacare-premiumsmedicaid.html (last accessed Jan. 28, 2021).

276 A 2018 report was authored by a number of health policy experts and academics examined lawsuits by hospitals in Texas. Called "Eroding the Public Trust," the authors noted that the "predatory billing practice of suing patients not only violates the public's trust, but also violates IRS criteria for many hospitals' tax-exempt status"). See Farah Hashim, et al., Eroding the Public Trust, A Report of Texas Hospitals Suing Patients, at 6 (2020), available at https://www.restoringmedicine.org/reports (last accessed Feb. 7, 2021).

277 See Mark Hall, Law, Medicine, and Trust, 55 Stan. L. Rev. 463 (2002).

278 See Castellucci, supra note 258 (noting "the strong body of evidence that shows mistrust leads to patient dissatisfaction and lower compliance with recommended treatment").

279 See, e.g., Martin Makary, Hospitals Go From Serving to Suing the

Poor, MEDPAGE TODAY, Sept. 9, 2019, available at https://www.medpagetoday.com/publichealthpolicy/healthpolicy/82040?xi d=nl_mpt_blog2019-09- 
To be published in 73 Hastings L.J. _ (forthcoming 2021-22).

will exacerbate a trend of declining trust between Americans and their health care system. ${ }^{280}$ Indeed, a recent Gallup poll reflected the number of Americans who have "confidence in the medical system" dropping from 80 percent in 1975 to just 38 percent in 2019. ${ }^{281}$

Health care affordability is a contributor to the decline in trust, ${ }^{282}$ and confusing medical advice during a catastrophic pandemic surely hasn't helped. ${ }^{283}$ Unexpected and unaffordable bills are particularly destructive to patient trust. ${ }^{284}$ This problem has been compounded by the fact that, historically, hospitals and physicians have not been wellequipped to discuss costs, even though that "for patients, affordability is critical to their personal decision-making and cannot be separated from clinical issues, such as when considering to pay the mortgage and grocery bill alongside needing a prescription or procedure." 285

09\&eun=g1354342d0r\&utm_term=NL_Gen_Int_Its_Academic_Active (last accessed Feb. 7, 2021) ("Money games and deceptive practices are eroding the public trust in the medical profession.”).

280 See Maria Castellucci, Hospitals, Physicians Try to Rebuild Trust with Patients, MODERn HEAlthCARE, Jun. 22, 2019, available at https://www.modernhealthcare.com/safety-quality/hospitals-physicianstry-rebuild-trust-patients (last accessed Feb. 8, 2021) ("The abundance of online health information, pressure on clinicians to shorten office visits, the rise in out-of-pocket healthcare costs and more awareness about surprise medical bills and physician conflicts of interest are among the likely contributors to the downward trend.").

281 See Richard J. Baron, Building Trust Can Improve American Healthcare, 7 Amer. J. ACCOUNTABLE CARE 24 (Sept. 19, 2019), available at https://www.ajmc.com/view/building-trust-can-improve-americanhealthcare (last accessed Feb. 8, 2021) (also noting that "data from the General Social Survey show that confidence in the people running medical institutions has also steadily dropped, from $61 \%$ in 1974 to just $37 \%$ in $2018 ”)$.

282 See Reshma Gupta et al., Rebuilding Trust and Relationships in Medical Centers: A Focus on Health Care Affordability, 324 JAMA 2361 (2020) ("One key contributor to this erosion in trust is likely related to health care affordability.").

283 See Sachin H. Jain et al., The Enduring Importance of Trust in the Leadership of Health Care Organizations, 324 JAMA 2363 (2020) ("Although the health care industry once enjoyed a high level of public trust, conflicting messages about the COVID-19 pandemic, ever-rising health care costs, news reports of greed, and other factors have conspired to erode that trust.").

284 See Gupta, supra note 282.

$285 I d$. 
To be published in 73 HASTINGS L.J. _ (forthcoming 2021-22).

Recent medical scholarship has focused on the goal of rebuilding patient trust. ${ }^{286}$ Some authors have specifically targeted high-deductible health plans (HDHPs) and costsharing in an effort to build a "higher-trust health system."287 This work maligns the "disconnect between a transparent and trustworthy system that treats patients as humans in need of care what many perceive as an increasingly consolidated, profit-driven system that treats patients as consumers buying goods and services." 288 Indeed, it's not difficult to understand how hospital lawsuits expose the dark underbelly of American health care's unsightly profit-driven machinery, and damage the ultimate goal of the entire enterprise-patient care.

\section{BANNING Hospital LaWSUtTS}

For better or worse, the American hospital is now the center of the American health care delivery system. Now more of the country's physicians are employees than owners. ${ }^{289}$ As physicians are less and less their own bosses, their decisional primacy may fade, or is at least burdened in different ways.

286 See id. ("Medical center leadership must acknowledge the foundational relationship between patient affordability and creating trusting, clinically effective relationships with patients.").

287 See Dhruv Khullar et al., Patient Consumerism, Healing Relationships, and Rebuilding Trust in Health Care, 324 JAMA 2359 (2020):

While consumerism was originally advanced as a means to empower patients by giving them choice and agency, it has more recently been used to simply shift costs from employers and insurers to patients.... This phenomenon is typified by marked growth in high-deductible health plans (HDHPs).... While patients deserve transparency around price and quality, a growing emphasis on consumer shopping and cost-sharing is unlikely to be productive."

$288 \quad I d$.

289 See Carol K. Kane, Updated Data on Physician Practice Arrangements: For the First Time, Fewer Physicians Are Owners Than Employees, AMA Policy Research Perspectives, 2019, available at https://www.ama-assn.org/system/files/2019-07/prp-fewer-ownersbenchmark-survey-2018.pdf (last accessed Feb. 8, 2021). 
To be published in 73 Hastings L.J. _ (forthcoming 2021-22).

Particularly noteworthy has been the increase in hospital-employed physicians. ${ }^{290}$ The change has been rapid. About 25 percent of physicians were employed by hospitals in 2012 , but 42 percent worked for hospitals by 2016. ${ }^{291}$ By January of 2018 , that number had risen to 44 percent. ${ }^{292}$ While some providers are happy to join hospitals as employees for stability and predictability, managerial support, and less legal exposure, ${ }^{293}$ with hospital employment comes the jettisoning of a professional autonomy. ${ }^{294}$ This may lead to a feeling that they are "losing control of their profession" in working for a business-driven boss, as "physicians find themselves working for non-physicians, individuals who never trained in the health professions or cared for the sick." 295 As a result, patient relationships "are now increasingly embedded in larger organizational contexts within medical centers."296 Patients are less likely to only interact with their provider, and instead, interact with the entire health care organization upon seeking care.

As the public becomes increasingly aware of hospital lawsuits, there may be an appetite for legislatures to act. ${ }^{297}$

$290 \quad I d$. ("In addition to changes in practice size, practice ownership is shifting away from physician-owned practice ('private practice') and toward working directly for a hospital or for a hospital-owned practice."). See also Alex Kacik, Rapid Rise in Hospital-Employed Physicians Increases Costs, MODERN HEALTHCARE, Mar. 16, 2018, available at https://www.modernhealthcare.com/article/20180316/TRANSFORMATI ON02/180319913/rapid-rise-in-hospital-employed-physicians-increasescosts (last accessed Feb. 8, 2021) ("from mid-2012 to mid-2016, the number of hospital-employed physicians hit about 155,000 in 2016 , up $63 \%$ from $95,000$ in $2012 ”)$.

291 Id.

292 See Les Masterson, Hospitals Now Employ More Than 40\% of Physicians, Analysis Finds, HealthCAREDive, Feb. 21, 2019, available at https://www.healthcaredive.com/news/hospitals-now-employ-more-than40-of-physicians-analysis-finds/548871/ (last accessed Feb. 8, 2021).

293 See Physicians Employed by Hospitals, MEDSCAPE, available at https://www.medscape.com/courses/section/891120 (last accessed Feb. 8, 2021).

294 Richard Gunderman, Should Doctors Work for Hospitals?, THE ATLANTIC, May 27, 2014, available at https://www.theatlantic.com/health/archive/2014/05/should-doctorswork-for-hospitals/371638/ (last accessed Feb. 8, 2021).

$295 \quad I d$.

296 Gupta, supra note 282.

297 See, e.g., Carol A. Clark, Senate Bill 71 to Protect New Mexicans From Medical Debt Passes First Committee Following Powerful Testimony, Los Alamos Daily Post, Feb. 6, 2021, available at 
To be published in 73 Hastings L.J. _ (forthcoming 2021-22).

Indeed, the bright spotlight of public attention has had an impact, ${ }^{298}$ sometimes just hours after reporting has focused national attention on hospitals' litigation policies. ${ }^{299}$ Recently, reflecting public pressure, hospital systems have "adjust[ed] ... financial aid guidelines," calling its policies "too aggressive." 300 Further, other states have established voluntary guidelines that "preclude hospitals from seeking to garnish patients' wages, file liens on their property or sell debt to a third-party entity without specific approval from the hospital's board of directors." 301

These are positive steps, considering how insidious hospital lawsuits are to patients and the health care system. Nonetheless, these steps highlight the need for a national, standardized solution to the problem of hospital lawsuits. Going forward, both law and ethics need to be recalibrated to address the problems that arise when hospitals sue patients.

The hospital lawsuit trend highlights the ineffectiveness of private insurance in shielding its beneficiaries from the cost of their health care. The

https://ladailypost.com/senate-bill-71-to-protect-new-mexicans-frommedical-debt-passes-first-committee-following-powerful-testimony/ (last accessed Feb. 7, 2021) ("SB 71, sponsored by Sen. Katy Duhigg, prevents hospitals - and third-party medical providers who bill separately-from sending to collections or filing medical debt lawsuits against people at or below 200 percent of poverty").

298 See Alia Paavola, Northwell's 2,500 Lawsuits Against Patients Made Headlines; Hours Later, They Were Rescinded, BECKER's HosPITAL REviEW, Jan. 8, 2021, available at https://www.beckershospitalreview.com/finance/northwell-rescinds-2500-suits-filed-against-patients-to-collect-unpaid-debt.html (last accessed Feb. 7, 2021) ("New Hyde Park, N.Y.-based Northwell Health will rescind thousands of lawsuits filed against patients for unpaid medical bills amid the pandemic"). It also has "decided to extend the pause on legal filings"). See also

299 See Selena Simmons-Duffin, supra note 4 ("The day after this story published, Mary Washington Healthcare announced it will suspend its practice of suing patients for unpaid bills").

300 Ruth Serven Smith, UVa Announces Plans to Forgive More Medical Debt, Adjust Collection Guidelines, The DAILy Progress, Sept. 13, 2019, available at https://dailyprogress.com/news/local/uvaannounces-plans-to-forgive-more-medical-debt-adjust-

collection/article_3f6414a5-295e-5f3f-b83c-e5521bd8541a.html (last accessed Feb. 7, 2021). See also Gupta, supra note 262 (noting how Ballad changed its fee structure and "increased its threshold for patients who were eligible for charity care from $200 \%$ to $225 \%$ of the federal poverty level").

301 Bannow, supra note 179. 
To be published in 73 Hastings L.J. _ (forthcoming 2021-22).

population of patients that hospitals could typically assume would be able to satisfy their portion of their hospital bills, patients with private plans now need additional protection. Put simply, hospitals should be prevented from suing their patients who cannot afford to pay. This legal solution could be an outright federal ban, and could, like in the proposed bill in New Mexico, ban lawsuits for patients of a certain socioeconomic status. ${ }^{302}$

It is not controversial for physicians to say that "there is a moral obligation to care for patients regardless of their ability to pay," 303 but the corollary moral imperative is to ensure that medically necessary care and emergency care does not result in an unsatisfiable financial obligation for the patients who need that treatment. Hospitals are no longer refusing to treat patients who cannot pay; instead, in these cases, they treat the patients, but then expect them to pay for their care and sue them to ensure that they do. The solution is a federal law that bans such behavior by hospitals.

Short of a hard law solution, another potential strategy would be to adjust the reimbursements for the hospitals that sue their patients. A typical tool for incentivizing certain behaviors and disincentivizing others, the Medicare program has increasingly used its reimbursement structure to reward high-quality care and penalize deficient or wasteful care for both physicians ${ }^{304}$ and hospitals ${ }^{305}$ through an increasing

302 See Clark, supra note 269.

303 Khullar, supra note 288.

304 For physicians, see, e.g., MIPS Scoring and Payment Adjustments, AMERICAN COLLEGE OF SURGEONS, available at https://www.facs.org/Quality-Programs/SSR/mips/scoring (last accessed Feb. 8, 2021) (noting that for "2020 MIPS participants, a maximum of a 9 percent payment adjustment is possible in calendar year 2022"); Quality Measures: APP Requirements, Quality Payment Program, available at https://qpp.cms.gov/mips/app-quality-requirements (last accessed Feb. 8, 2021) (presenting the quality metrics).

305 See Jordan Rau, Look Up Your Hospital: Is It Being Penalized By Medicare?, KAISER HEALTH NEWS, Nov. 2, 2020, available at https://khn.org/news/hospital-penalties/ (last accessed Feb. 8, 2021) (noting that, through the Hospital Readmissions Reduction Program, "Medicare cuts as much as three percent for each patient"); Jordan Rau, Medicare Fines Half of Hospitals for Readmitting Too Many Patients, KAISER HEAlth News, Nov. 2, 2020, available at https://khn.org/news/medicare-fines-half-of-hospitals-for-readmittingtoo-many-patients/ (last accessed Feb. 8, 2021) (noting that "nearly half of the nation's hospitals" were subjected to a readmissions penalty under the Medicare readmissions program). 
To be published in 73 Hastings L.J. _ (forthcoming 2021-22).

number of modern initiatives. ${ }^{306}$ Similarly here, Medicare could reduce reimbursements to the hospitals that pursue litigation against their patients, effectively neutralizing the incentive to collect on those bills through penalty. This would be an easier reimbursement-based regulatory answer that may be simpler to achieve.

\section{CONCLUSION}

When hospitals sue former patients, American health care and patient wellbeing loses. The lawsuits cause harm to the public health, to health care policy, to the organization of health care finance, and they erode patient trust. Above all, they demonstrate the absence of a moral tether that guides the work of the hospital, and lays bare the failure of the consumer-based paradigm in American health care. In order to bring hospital strategies into alignment with public interests, protect the health of the public, and realign policy goals within American medicine, hospital lawsuits must become a relic of the past.

306 See, e.g., Hospital-Acquired Condition Reduction Program (HACRP), Centers for Medicare and Medicaid Services, Feb. 11, 2020, available at https://www.cms.gov/Medicare/Medicare-Fee-forService-Payment/AcuteInpatientPPS/HAC-Reduction-Program (last accessed Feb. 8, 2021) (noting that the program "requires the Secretary of Health and Human Services (HHS) to adjust payments to hospitals that rank in the worst-performing 25 percent of all subsection (d) hospitals with respect to HAC quality measures"); Jordan Rau, Preeminent Hospitals Penalized Over Rates of Patients' Injuries, KAISER HEALTH News, Jan. 31, 2020, available at https://khn.org/news/medicarepunishment-hac-preeminent-hospitals-penalized-for-rates-of-patientsinjuries-medicare-hospital-acquired-conditions-reduction-program-aca/ (last accessed Feb. 8, 2021) (noting that there were 786 hospitals in 2020 that were set to have their reimbursements reduced under the HACRP. As of the beginning of 2020, more than one-third of the nation's hospitals have been subjected to a penalty under the program. Id. 